\title{
Dimensions of social meaning in Post-classical Greek
}

\section{Towards an integrated approach}

\author{
Klaas Bentein \\ Ghent University \\ Klaas.Bentein@UGent.Be
}

\begin{abstract}
Especially in the first half of the twentieth century, language was viewed as a vehicle for the transmission of facts and ideas. Later on, scholars working in linguistic frameworks such as Functional and Cognitive Linguistics, (Historical) Sociolinguistics and Functional Sociolinguistics, have emphasized the social relevance of language, focusing, for example, on linguistic concepts such as deixis, modality, or honorific language, or embedding larger linguistic patterns in their social contexts, through notions such as register, sociolect, genre, etc. The main aim of this article is to systematize these observations, through an investigation of how the central, though ill-understood notion of "social meaning" can be captured. The starting point for the discussion is the work that has been done in the framework of Systemic Functional Linguistics (SFL). This framework distinguishes "social" ("interpersonal") meaning from two other types of meaning, and offers a typology of different types of contexts with which these different meanings resonate. In order to achieve a more satisfactory account of social meaning, however, I argue that we need to connect SFL to a theory of how signs convey meaning. The discussion is relevant for Ancient Greek in its entirety, but focuses specifically on Post-classical Greek: as a case study, I discuss five private letters from the so-called Theophanes archive (IVAD).
\end{abstract}

\section{Keywords}

social meaning - Systemic Functional Linguistics - indexicality - Post-classical Greek Theophanes archive 
As Butler (2008: 43) notes, "many linguists, and in particular semanticists, have treated language as if it were solely, or at least primarily, a vehicle for the transmission of facts and ideas". ${ }^{1}$ Various ideological and cultural reasons can be taken to underlie such a neglect of the "social" or "interpersonal" realm (cf. Stankiewicz 1964; Poynton 1990: 2-25): the firm belief that cognitive (referential) elements of language are basic and form its central core; the consideration of pairs such as "langue" and "parole" as dichotomous, rather than dialectic; assumptions that interpersonal features in language are unpredictable and lack systematicity (whereby the categorical is privileged over the probabilistic); etc.

Since the 196os/1970s, however, scholars working in frameworks such as Cognitive and Functional Linguistics, (Historical) Sociolinguistics and Functional Sociolinguistics have stressed the intimate relationship between language and society, so much so that context has come to play a central role in linguistics, as Hasan (2001:2) writes:

Today, except perhaps for a die-hard minority, the notion of context has captured a centre-stage position so that concern with context-or more accurately, the perspective adopted on context-defines one's location within the now much more enriched discipline of linguistics.

With regard to Ancient Greek, ${ }^{2}$ too, scholars have studied the social function of language, focusing, for example, on linguistic concepts such as honorific language, modality or deixis (see e.g. Dickey 1996; Edmunds 2008; Van Rooy 2016), or embedding larger linguistic patterns in their social contexts, through notions such as register, sociolect, genre, etc. (see e.g. Willi 2010, 2017 on Classical Greek; Bentein 2013 on Post-classical Greek).

The main aim of this article is to systematize these observations by examining how the central notion of "social meaning" can be captured. For this purpose, I explore recent insights from disciplines such as sociolinguistics, semiotics, and linguistic anthropology, and see to what extent they can be applied to Ancient Greek, Post-classical Greek in particular (and by extension, whether

1 Thompson \& Hunston (2000: 22) refer to a "propositional" or "content" perspective on language; cf. Lyons (1977: 50).

2 Ancient Greek is traditionally subdivided into a number of periods, including Archaic Greek (VIII-VI BC), Classical Greek (V-IV BC), and Post-classical Greek (III BC-VI AD). 
the Ancient Greek data call for a modification of such insights). My main point of focus will be the work of Michael Halliday and his followers, who established the framework of Systemic Functional Linguistics (SFL) (see e.g. Halliday \& Matthiessen 2014 for an extensive overview of the theory). More so than most other linguistic theories, SFL has been engaged with situating language in its social context for almost half a century now (cf. Van Dijk 2008: 55). The value of this framework for corpus languages such as Ancient Greek has been stressed on various occasions (most recently Porter 2016).

Throughout the twentieth century, scholars have advanced a number of typologies of the concept of "meaning", which they have related to the different functions of language. Leech (1981: 9-23), for example, distinguishes between as many as seven types of meaning: "conceptual", "connotative", "social", "affective", "reflected", "collocative", and "associative". More well known is the older model by Bühler (1934), who proposed a tripartite classification of meaning/ function into "representative" (Darstellung), "expressive" (Ausdruck), and "vocative" (Appell), corresponding to the three essential components of the speech act, that is, the speaker, the addressee and the external situation to which reference is made. Bühler's (1934) model was later extended by Jakobson (1960), who substituted "vocative" with "conative", "expressive" with "emotive", and "representative" with "referential", and added three more functions/types of meaning: "metalinguistic", "phatic", and "poetic" (for other proposals, see, among others, Hymes 1961; Nuyts 1989; Robinson 2003; Van Dijk 2008: 42).

The model which I will focus on here, first proposed by Halliday (see e.g. 1970, 1978), also distinguishes between three types of function/meaning (socalled "metafunctions"), which are called "ideational" (the use of language to express experiences, and the participants/processes/circumstances contingent on those experiences), "interpersonal" (the use of language to express opinions and to interact with people), and "textual" (the use of language to create coherent texts). As Butler (2008: 43) notes, an important difference between Bühler and Jakobson on the one hand and Halliday on the other is that whereas the former view language from the outside, Halliday hypothesizes that the basic functions or metafunctions are reflected in language itself: he claims that the semantic and lexicogrammatical "systems" that can be found in language can be systematically related to one of the three metafunctions (cf. Halliday \& Matthiessen 2014: 666). So, for example, TrAnsitivity is said to be related to the ideational metafunction, COHESION to the textual metafunction, and MOOD to the interpersonal metafunction. What makes Halliday's model even more interesting is that Halliday explicitly connects the functions of language not only to language but also to social context: Halliday argues that the three metafunctions of language systematically resonate with three "vectors of con- 
text". ${ }^{3}$ These three vectors are called "Field", "Tenor", and "Mode", Field referring to what is going on in the situation, Tenor to who is taking part in the situation, and Mode to how the interactants come into contact. Halliday's hypothesis is that Field systematically relates to the ideational metafunction, Tenor to the interpersonal metafunction, and Mode to the textual metafunction.

Together, these three contextual parameters make up the immediate context or "context of situation". Halliday and his followers also recognize a second layer of context, which is called the "context of culture". Here, genres can be located, which can be thought of as stable configurations of Field, Tenor and Modevalues which have become institutionalized through regular co-occurrence (cf. Eggins 2004: 58). From this perspective, a culture can be seen as a system of genres. As Bakhtin (1986: 79) notes, without the existence of such fossilized cultural patterns, interpersonal communication would be very hard:

If speech genres did not exist and we had not mastered them, if we had to originate them during the speech process and construct each utterance at will for the first time, speech communication would be almost impossible.

One aspect that is absent from Halliday's model, even though explicitly called "semiotic", ${ }^{4}$ is a theory of how signs convey meaning. ${ }^{5}$ Bühler (1934), for example, explicitly notes that his three types of meaning can be connected to three different types of signs, which he calls "symptoms", "symbols" and "signals", but a similar perspective cannot be found in Halliday's work. Most well-known in this regard is of course Peirce's (1933[1885]) trichotomy between "symbol", "icon" and "index". These three types of signs can be distinguished on the basis of the relationship between the sign (the significans) and the signified (the significatum): with icons and indexes, this relationship is motivated, but on different grounds (resemblance vs. contiguity), whereas with symbols it is arbitrary.

3 Van Dijk (2008: 44) notes that this view of the relationship between context and language makes the theory rather static and deterministic, as there is little room for individual variation and agency. To some extent, this issue is resolved by the view that the relationship between text and context is probabilistic in nature (see e.g. Halliday 1991). A more fundamental solution is offered by Lecky-Tarrie (1995), who introduces an interface between text and context: she argues that "it is not the context categories themselves that influence the meaning and the form of the text, but rather the knowledge the participants have of the variables of these categories" (Van Dijk 2008: 49).

4 See the title of Halliday's 1978 book, Language as a Social Semiotic.

5 Halliday has been criticized for this omission. See e.g. Sowa (2001: 141-142). 
Whereas language is typically thought of as a symbolic system, it is not exclusively so. ${ }^{6}$ In fact, in recent years, scholars have drawn attention to the central importance of linguistic indexes for conveying social meaning: as Silverstein (2003: 194-195) notes, any sociolinguistic fact is necessarily also an indexical fact. Linguistic indexes are "structures" (lexemes, affixes, diminutives, syntactic constructions, emphatic stress, etc.) that have become conventionally associated with a particular situational dimension, and that invoke that situational dimension whenever they are used (cf. Ochs 1996: 411). Various scholars have noted in this regard that indexes do not form a homogeneous category and have therefore proposed classifications of indexicality. Lyons (1977: 108), for example, suggests that indexes should be subclassified into "individual-identifying" and "group-identifying", and that the latter type can then be further subdivided into "region-identifying", "status-identifying", "occupation-identifying", etc.

Another proposal, to which I will refer in the remainder of this article, was made by Silverstein (1976). Silverstein (1976) proposes to distinguish between "referential" indexes and "non-referential" indexes: while the former are inherently indexical (for example deictics such as "now", "then"), the latter are not inherently so (for example copula omission as a marker of African American Vernacular English). A related proposal was made by Ochs $(1992,1996)$, who distinguishes between "direct" and "indirect" indexicality, thereby focusing more on the phenomenon of indexicality than on the indexicals themselves. Scholars have noted some fascinating linguistic and contextual differences between these two types of indexes/indexicality, which, as becomes clear, can be observed in Ancient Greek as well.

This article is structured as follows: in Section 2, I introduce the sample texts that serve as the basis of discussion. In Section 3, I discuss how language indexes different aspects of social context, both directly and indirectly. In Section 4, I go further into the relationship between these different types of social meaning. I conclude the article in Section 5 .

6 This symbolic (arbitrary) nature of language was one of the cornerstones of De Saussure's linguistic theory. In the meantime, some scholars have argued that signs are never completely arbitrary. See e.g. Kress (1993: 173): "the relation of signifier to signified, in all human semiotic systems, is always motivated" (emphasis added/Кв). Hodge \& Kress (1988: 21-22) propose a continuum ranging from arbitrary to motivated. 
Many, if not most, sociolinguistic studies of Ancient Greek have focused on the Classical period, in particular authors such as Aristophanes and Plato. As I have noted in the past, this is, to some extent, surprising, since "the situational characteristics of our Post-classical textual witnesses diverge to a much greater extent than what is the case for Classical Greek" (Bentein 2013: 35). For Postclassical (and Byzantine) Greek, we not only have literary texts ranging from high-level Atticistic Greek (e.g. historiography, the novel) to lower-level Koine Greek (e.g. scientific prose, hagiographical texts), but also tens of thousands of contextually diverse documentary texts which have only recently started to be studied intensively from a linguistic point of view.

Of particular value within the documentary corpus are texts contained within so-called "archives" (collections of texts). As Vandorpe (2010:159) notes, "whereas individual texts are like instant snapshots, archives present a coherent sequence of pictures of a person or a family". Among others, archives allow us to linguistically compare texts written by one and the same sender to one or more addressees, or from one or more senders to one and the same addressee. It is on one such archive that I focus here, the fourth-century Theophanes archive (publications on the archive include Rees 1968; Moscadi 1970; Matthews 2006; Choat 2009). This archive is quite varied: it contains public documents, letters, itineraries, accounts and memoranda (cf. Matthews 2006: xv-xvi). All these texts are in Greek, except for two Latin letters (P.Ryl. IV 623 and P.Argent.Lat. 1). The main figure of the archive, Theophanes, was an influential and highstanding resident of Hermopolis Magna in the beginning of the fourth century, where he worked as a scholasticus (lawyer). It has been suggested that Theophanes was employed at a high level of the Egyptian administration, but this remains uncertain (cf. Choat 2oog: 47-48). Theophanes did hold a number of local, public offices in Hermopolis: he was an exactor, gymnasiarch and councilor.

There has been some debate about Theophanes' social circle: whereas earlier accounts saw Theophanes as the leader of a cultured, pagan circle (Rees 1968: 165), worshiping Hermes Trismegistus and maintaining its Greco-Egyptian culture as the Eastern Empire slowly turned Christian, more recently scholars have suggested that Theophanes and his family may not have been worshippers of Hermes at all, and that Theophanes' family and close circle also contained Christians.

Theophanes is best known for the journey he undertook from Hermopolis to Antioch, ${ }^{7}$ during which time letters were sent or given to him. The journey

7 As Matthews (2006: 8) notes, the journey in itself was not extraordinary-it was commonly 
itself is usually placed in a date range from 317 to $323 \mathrm{AD}$. Overall, we have no clear idea of what Theophanes was doing in Antioch, "except that he may have been on semi-official business involving financial matters, and that he may have delivered some petitions" (Choat 2009: 55). Rees (1968: 181-182) has suggested that Theophanes undertook the journey to Antioch in order to represent the interests of the pagans at Hermopolis, but such a hypothesis finds no confirmation in the actual texts (cf. Choat 2009: 51).

From the ten private letters in the archive, I have selected five as a case study for the present discussion. Even though this is not a large sample, it is sufficient for a qualitative analysis of how social meaning is established in Ancient (Post-classical) Greek. So as not to be unnecessarily long, I have chosen to only reproduce the English translation of the texts here. The full Greek text can be found online at Papyri.Info, with reference to the printed editions (P.Herm., P.Ryl.IV, Sв XII). Before proceeding with the analysis, I briefly introduce and contextualize each of the letters in what follows. The translations are borrowed from Matthews (2006).

The first letter here (P.Herm. 6) was written to Theophanes by a certain Besodorus. Little is known about Besodorus: based on the letter that is preserved, he must have been a close acquaintance with shared business interests. Matthews (2006: 25) draws attention to Besodorus' theophoric name, which may be indicative of a pagan background. His name is derived from the Egyptian dwarf-god Bes, one of whose functions it was "to promote fertility in marriage and to protect in childbirth" (Matthews 2006: 25); Besodorus was thus called "gift of Bes". Others, however, have drawn attention to the monotheistic phraseology present in Besodorus' letter, in particular the reference to "the highest god". In principle, this could also be taken as a reference to Hermes Trismegistus, but there is no secure non-Christian usage of such a phrase after the early Roman period (Choat 20og: 66). Besodorus writes from Alexandria, where, Rees (1968: 173) suggests, Theophanes left his sons in the care of Besodorus.

\section{Text 1: Letter from Besodorus to Theophanes (P.Herm. 6) ${ }^{8}$}

To my lord and brother Theophanes, Besodoros, very many greetings. In truth, there was in me a longing for you, one that rested heavy on my mind, my lord brother, which, on each bright presence of yours in the

made. In fact, another letter mentions Alexandria as Theophanes' destination, so Theophanes must have been what Matthews (2006: 20) calls a "frequent traveler".

8 The full Greek text can be found at http://papyri.info/ddbdp/p.herm;;6. 
city, caused me by the mere glimpse of you to be filled with pleasure and to find all I wished for. But now, this short period of your absence has made the sight of you more desirable to us who pray to see it; since even the few moments of time spent in sleep seem immeasurably long to those who pine away with love. And so I, suffering like a lover, pray to be released from such longing, just as soon as it is my good fortune to see you. My feelings in this matter, as I inquire on every possible occasion of the strangers that come from anywhere on earth to stay here with us, would be laborious and long to explain; for there is nothing more precious or more powerful than a brother's ... [7-8 words missing]. And now it is a matter of concern to me, and devoutly to be wished, to learn exactly what is the outcome of the affairs you have set in order, so that I too may heartily rejoice over matters in which I raised my voice loudly and publicly; for I have an explicit trust and confidence that nothing untoward or improper will happen, if the god supports you in every enterprise, in matters where justly ... [3-4 words missing] to do good on my own account. For the virtuous among men, all kinds of honours are held in store by god. And so, my lord brother, may it be that you will return in good health to your native city, having put these matters to rights. It will be with joyful pleasure on our part that you will return to your city ... [10-15 words missing]. Then I would offer full gratitude to the highest god, if I could see with my own eyes how things are with you, having from the beginning set out with you on the same journey. But now I wish and pray, by any means whatever to hear more clearly news of this and to learn how matters stand with you. I send you many greetings, true brother of my soul, and all who are with you by name. 2 nd, i.e., Besodorus's own, hand May I receive you back in good health, my master and brother, having splendidly accomplished the things we wish for. Address on verso (in 2nd or 3rd hand) Deliver to my lord brother Theophanes, from Besodoros.

tr. MATTHEWS 2006

In the next letter (P.Ryl. IV 624), we are introduced to two of Theophanes' sons, Hephaestion and Horigines, who thank their father for allowing them to travel to a city (presumably Alexandria), to see the business he was conducting there. Several scholars have noted that this letter was written by the same scribe as the letter from Besodorus (cf. Matthews 2006: 28). Rees (1968:172) considers it likely that this scribe was the boys' tutor, and that Besodorus "may well have been in some way responsible for the care and supervision of the two young men", though he probably was not their tutor himself, but rather the tutor's employer (cf. Rees 1968: 174). Regrettably, this letter is in a worse condition than the other 
texts discussed here: in the translation, $[\ldots]$ is used to indicate small gaps of a couple of words; otherwise an estimate of the number of missing words is given.

\section{Text 2: Letter from Hephaestion and Horigines to Theophanes (P.Ryl. Iv 624) ${ }^{9}$}

To our lord and master, our father Theophanes, Hephaistion and Origenes, many greetings. We do not think the pains of our journey [...], our lord father, worthy of any particular recompense [...], since we chose on our own account to endure them. On the contrary, we have a sense of gratitude, which we also expressed earlier, for being esteemed worthy of such honor, from which we were able to know exactly [...] affairs [...] through being present and seeing for ourselves, without being seriously disappointed in our wishes [...]. We stayed on in the city after you had left us there, making fond inquiries in matters concerning your success and wellbeing(?), from which us too ... [about 20 words missing, but with the financial terms mentioned above] ... the matter concerning you. For this especially we consider to be a prime duty and one surpassing all others; the law of nature teaches us to care and take thought for no other person more than for a good father: from which (or, from whom) derives also an unchallenged repute in the city, and the ability to disdain those who are otherwise minded. This is the easiest thing for us, since you well know how with all our might we are so disposed, and with (all) our soul... [about 35 words missing] ... being willing to travel with you [...] no foreign customs(?) would stand as an obstacle; no love of elders, nor pleasure of home; nor any other such consideration [...]. For we would declare especially ... [c. 5 words] ... of the healthy and living (pl.) ... [c. 12 words] ... we all greet you, lord father ... [c. 5 words] ... may you live the rest of your days ... [c. 5 words] ... accomplishing (sing.) your will ... [c. $7-8$ words] ... most honoured [... Fragmentary greeting, in 2nd hand: [...]] Address on verso: [To our] lord (?) [...]

tr. MATTHEWS 2006

In the next letter (P.Herm. 5), more about Theophanes' family is revealed: two more sons are mentioned, Anysius and Aphthonius, some unnamed sisters, as well as Theophanes' wife, all of whom had stayed behind in Hermopolis while their father/husband was traveling. The letter itself is written by a certain

9 The full Greek text can be found at http://papyri.info/hgv/32762. 
Hermodorus, who, Matthews (2006: 23) suggests, may have been Theophanes' brother-in-law, since he seems to be so closely related with the rest of the family. One argument in support of this position is the fact that Hermodorus refers to Anysius and Aphthonius as "our" sons..$^{10}$ Matthews (2006: 23) considers this "a gentle way of adding his [Hermodorus'] own affection to the good report he sends of the two young men, his own nephews".

\section{Text 3: Letter from Hermodorus to Theophanes (P.Herm. 5) ${ }^{11}$}

[To my lord brother, Theophanes] Hermodoros, greeting. I take delight in writing to you and I pray that my letter is given to you in good health and spirits. It is right and proper that you also, when writing to others, remember us too, so that our pleasure may be greater, learning from your letters of your safety and good health, for which we pray. And may it come about that we soon enjoy the greatest gladness on your account, for which we pray and hope to enjoy through the kindness of the omnipotent deity, receiving you back strong in soul and body, and crowned with success. Be in good heart also on account of our sons Anysios and Aphthonios, for they are in good health and are fulfilling their obligations, attending to their business at the same time as to their civic duties. In good health too are their sisters and their mother, and all those in your house. Your sister sends many greetings, and our children, and all those in our house. I pray for your good health for many years, my lord brother, and may we receive you back speedily, in good heart in all respects. Pachon 26. Address on verso: To my brother Theophanes, Hermodoros.

tr. MATTHEWS 2006

The fourth letter (P.Herm. 4) stands out because of its brevity: it is a note from Iohannes and Leon containing nothing more than formal greetings expressed in conventional phrases. Since Iohannes and Leon address Theophanes as agapètòs adelphós "beloved brother", scholars have suggested that the two writers must have had a Christian background. The brothers mentioned at the end of the letter may then be considered a group of religious males, perhaps living, as Matthews (2006:29) suggests, in an early monastic community. Whereas Matthews (2006: 29) highlights the distinct character of this letter, Choat (2009:

\footnotetext{
10 Note, however, that confusion between hēmôn and humôn is common in the papyri, so that we may simply be dealing with a mistake (cf. Choat 2009: 45-46, fn. 23). On the other hand, orthographic mistakes are extremely rare in the Theophanes archive.

The full Greek text can be found at http://papyri.info/ddbdp/p.herm;;5.
} 
63) notes that it was actually written by the same scribe as our previously mentioned letter, P.Herm. 5 (Hermodorus to Theophanes). This could be taken as an indication of the fact that Hermodorus, too, had a Christian background, and that the reference to "the omnipotent deity" in this letter is in fact a Christian reference. Choat (2009: 65) suggests that Hermodorus may have been the scribe of both letters.

\section{Text 4: Letter from Iohannes and Leon to Theophanes (P.Herm. 4) ${ }^{12}$}

To Theophanes, our beloved brother, Ioannes and Leon, greeting. We thought ourselves in duty bound to address you in writing, praying that the letter is given to you in good health, and in all respects in good spirits. We pray also soon to receive you back in good health. All the brothers who are here greet you, and Dionysius from Attinu, who met you at Athribis. We pray for your health for many years. Address on verso: To Theophanes our beloved brother, Ioannes and Leon.

tr. MATTHEWS 2006

Besides letters addressed to Theophanes, our archive also contains letters carried by Theophanes on behalf of others, in which his name is mentioned.13 The fifth and final letter here (P.Herm. 2) belongs to this second category: it was written by a certain Anatolius, ${ }^{14}$ who was chief prophet (arkhiprophétēs) of Hermopolis, and one of the people in the archive who was incontestably involved in the worship of Hermes Trismegistus. The addressee is a certain Sarapion, about whom there is no further information. Matthews (2006: 20) suggests that the letter was given to Theophanes when he embarked on a completely different journey from the one to Antioch described above, but Choat (2009: 57) thinks there is little reason for such an argument.

\section{Text 5: Letter from Anatolius to Sarapion (P.Herm. 2) $)^{15}$}

To my master Sarapion, Anatolios, greetings. You know, my lord, that I pray both to see and speak with you face to face, for you are my cham-

\footnotetext{
12 The full Greek text can be found at http://papyri.info/ddbdp/p.herm;;4.

13 Matthews (2006: 20) notes that the letters "were given to Theophanes to be delivered to their recipients when he reached his destination, or else in some place he passed on the way there". They may have been retained by him because he was unable to deliver them.

14 Anatolius is also the author of P.Herm. 3 and SB XII 10803.

15 The full Greek text can be found at http://papyri.info/ddbdp/p.herm;;2.
} 
pion and, among champions, most admirable. Indeed, often as I was full of eagerness and on the point of effecting it, when reasons quite inescapable prevented me from reaching you — on the one side my daughters' illnesses (which the capricious malice of some god visited upon me, yet may he remove it), on the other the compelling duty of worship of the god Hermes, our guardian. In fact, I would at this very moment have been on the road with distinguished traveling company, matching the exacting demands of your character-for my lord brother, my [master?] Theophanes, in whom I have great faith, is about to leave home [about 15 words missing, in which Anatolius must have renewed his excuses for not visiting Sarapion in person] ... the observance of the sacred month Pharmouthi having begun, in which many processions take place one after the other in due order, at which I must be present for both of two reasons, the worship due to the deity and the excellent opportunity it provides to offer prayers for your safety and good name. But I shall come, if the gods offer their help and make it possible, after the time of the observance of Pharmouthi. May you enjoy everlasting happiness, my lord, and may the gods attend you and be kindly. Address on verso: To my master Sarapion, Anatolios.

tr. MATTHEWS 2006

Before proceeding with the analysis, some words need to be said about the nature of the texts. Modern-day investigations into the social nature of language are, to a large extent, based on dialogic speech events, in which at least two participants are physically present and communicate with each other. Scholars have drawn attention to the dynamic nature of contextualization in such cases, context being constantly renegotiated through the use of language (what Gumperz 1982 has called contextualization cues). Studies of Ancient Greek, on the other hand, largely have to work with monologic texts, ${ }^{16}$ where an audience does not or cannot respond, and renegotiation of context is impossible. While we need to be aware of the impact of monologic texts on social context (for example, addressees necessarily being positioned as non-equals, because of the non-reciprocal nature of communication) and linguistic choice (for example, intonation and stress playing a much less important role), in itself working with monologic texts does not stand in the way of the analysis of social meaning. As Poynton (1990: 97) notes, some monologic texts, such as private letters, "seem to more obviously position readers interpersonally than others".

16 On the notion of monologic text, see further Poynton (1990: 96-99). 
In the case of our texts, the senders were very conscious of who they were writing to. In fact, if dialogic and monologic texts were seen as forming a continuum (cf. Poynton 1990: 98), our texts would be quite near the dialogic end.

\section{3}

\section{Social meaning}

Now that we have established that social meaning is brought about through indexical linguistic structures, and have selected our case study, we can proceed to the actual analysis. As already mentioned, the discussion is based on the distinction proposed by Silverstein (1976) and Ochs (1992) between "direct indexicality", as established by referential indexes, and "indirect indexicality", as established by non-referential indexes. More specifically, my point of interest with each of these two subfields of indexicality is the following: what kind of linguistic structures ${ }^{17}$ serve as referential and non-referential indexes respectively, and what kind of contextual aspects do they index? Before answering this question, we first need to get a better grasp of how context can be understood, and what contextual levels can and should be distinguished. ${ }^{18}$

\subsection{Contextual levels}

Recent scholarly work has stressed the importance of distinguishing between different contextual levels: Moore \& Podesva (2009), for example, distinguish between the micro-, meso-, and macro-social level, ${ }^{19}$ corresponding to micro-, meso-, and macro-social meanings (compare Bucholtz \& Hall 2005: 592; Coupland 2007: 113-114). Halliday and his followers, as noted in the introduction, describe context in terms of two (rather than three) planes, the context of situation (the immediate, situational context), and the context of culture (the larger, cultural context). The context of situation is determined by three vectors of context, Field, Tenor, and Mode, each of which can be further specified. For the specification of Tenor, ${ }^{20}$ which is directly related to the interpersonal/social

17 Prosody is known to play an important role when it comes to expressing social meaning (see e.g. Auer 1996:4), but for a corpus language such as Ancient Greek must be left out of the investigation.

18 This is of course a notoriously difficult question, an exercise in "capturing infinity" according to Cook (1990). See Van Dijk (2008, 2009) and Hasan (2009) for further discussion.

19 The debate between the micro- and macro-level, and how to integrate them, has a longstanding tradition in sociology (see e.g. Knorr-Cetina 1981).

20 Poynton (1990:50) explicitly notes that her model of the Tenor-variable is not based on a priori grounds, but rather on "the prior identification of the three independent real- 
TABLE 1 Tenor and its subparameters

\begin{tabular}{l|l|l}
\hline Hasan $(1989,1999)$ & Poynton $(1985,1990)$ & Martin \& White (2005) \\
\hline $\begin{array}{l}\text { Agentive role } \\
\text { e.g. "symmetrical" vs. "asymmetrical" }\end{array}$ & $\begin{array}{l}\text { Power } \\
\text { e.g. "equal" vs. "unequal" }\end{array}$ & Power (status) \\
\hline $\begin{array}{l}\text { Social hierarchy/social role } \\
\text { e.g. "male" vs. "female" }\end{array}$ & $\begin{array}{l}\text { Contact } \\
\text { e.g. "frequent" vs. "occasional" }\end{array}$ & Solidarity (contact) \\
$\begin{array}{l}\text { Social distance } \\
\text { e.g. "maximal" vs. "minimal" }\end{array}$ & $\begin{array}{l}\text { Affective involvement } \\
\text { e.g. "high" vs. "low" }\end{array}$ & \\
\hline
\end{tabular}

metafunction, two main proposals have been made, by Hasan $(1989,1999)$ and Poynton $(1985,1990)$ respectively. ${ }^{21}$

Table 1 shows that these two major proposals actually have many similarities: Hasan's "agentive role" resembles Poynton's "power", and Hasan's "social distance" resembles Poynton's "contact". The two proposals have a different focus, however: Hasan introduces an extra category of social hierarchy/social role, which resembles agentive role, but not entirely: a person can be socially hierarchical, but still assume a symmetrical agentive role. Poynton, on the other hand, assumes an extra category of affective involvement, which is similar to contact, but not entirely: people can come in frequent contract, but still have low affective involvement. As Table 1 shows, Martin \& White (2005) have recently proposed to posit two major Tenor-axes, "power" and "contact", which they consider as "the vertical and horizontal dimensions of interpersonal relations" (2005: 29) (compare already Brown and Gilman 1960).

With the exception of Poynton's "affective involvement", all of the Tenorparameters mentioned in Table 1 seem to concentrate on the higher social levels (with agentive role/power and social distance/contact at the meso-level, and social hierarchy/social role at the macro-level, although it is hard to make a distinction between the meso- and macro-level). As we have seen, the second

isational strategies deployed in the use of interpersonal forms", which she refers to as "reciprocity", "proliferation", and "amplification".

21 A third proposal, which I do not discuss here, has been made by Leckie-Tarry (1995). 
contextual plane posited by SFL, the context of culture, too, is exclusively concerned with the macro-social level. Such an emphasis is not entirely surprising, of course, since Systemic Functional Linguistics as a functional linguistic theory aims to explain linguistic regularities, which are typically related to higher contextual levels.

As for Poynton's affective involvement, Martin \& White (2005: $31-32)$ explicitly argue that it belongs to the linguistic, rather than the contextual level. As Table 1 shows, these scholars argue for a model with two major Tenorparameters, "power" and "solidarity". They view Poynton's "affective involvement" as a "discourse-semantic" system, which they rename APPRAISAL, and which they consider in terms of three interacting domains, called "Attitude", "Engagement", and "Graduation". ${ }^{22}$ As Auer (1996:4) notes, however, a broad reading of context-dependence also includes what may be called "subjectivity": "his or her [the speaker's] life-world, likings and dislikings, identification with persons or events referred to, etc., is reflected in and indexed by syntax and morphology, lexicon and prosody". In other words, an attempt should be made to include the "personal" into the interpersonal, not only at the linguistic, but also the contextual level. ${ }^{23}$ Such a broad understanding of "interpersonal" has been argued for by Poynton (1990: 18), for example when she describes it as "incorporating ... both the interactive and the personal, the social and the individual".

Next to affective involvement, there is another type of micro-level social context that is not well integrated in the Systemic Functional model: the spatiotemporal setting of the event. Some scholars have included setting under the Field-parameter (see e.g. Leckie-Tary 1995: 36$)^{24}$ without much further explanation, whereas others have explicitly excluded it, by making a distinction between "context of situation" and "material situational setting" (see e.g. Hasan 1985: 99; 1996), ${ }^{25}$ the former being "a theoretical construct abstracted for metalinguistic purposes" (Cloran 1999:178), and the latter an interactional frame consisting of "the human and non-human entities and their attributes, any ongoing non-verbal activities or states, and any circumstances, e.g. time of day etc." (Cloran 1999: 178). In similar vein, Van Dijk (2008: 31) refers to things or persons present in the current situation as the "referential" or "semantic" context, which, he argues, should be distinguished from the "pragmatic" nature of

\footnotetext{
22 See further Section 3.2.2.

23 For a critique of Martin \& White's (2005) argument, see Poynton \& Lee (2009).

24 Halliday (1978) recognizes "institutional setting" as a component of the Field-parameter.

25 Compare the distinction made by Ellis (1966: 82) between "immediate situation" and "wider situation".
} 
TABLE 2 Contextual levels

$\begin{array}{lll}\text { Material situational setting } & \text { Setting } \\ \text { Context of situation (Tenor) } & \text { Stance } \\ & \text { Social identity } \\ \text { Context of culture } & \begin{array}{l}\text { Social act } \\ \text { Social activity }\end{array}\end{array}$

the real, social context, such as the roles of the participants, etc. (Van Dijk 20o8: 31; 20o9: 191, 194). Of course, within an indexical approach to social meaning, both referential (semantic) and non-referential (pragmatic) aspects of context need to be taken into account. ${ }^{26}$ As we see in Section 3.2.1, elements relating to the setting have linguistic importance, too.

Table 2 gives an overview of the contextual levels which I consider to be relevant. Following SFL, I distinguish between three contextual planes, called "material situational setting", "context of situation", and "context of culture". As the arrow in the right of the Table shows, these different contextual planes form a continuum from the micro- to the macro-social level. In order to be more explicit about the different dimensions that make up these three contextual planes, I subdivide context of situation (Tenor in particular) into "stance" and "social identity", and context of culture into "social act" and "social activity", following the pioneering work of Ochs (1996).

\subsection{Direct indexicality}

3.2.1 Setting

As Ochs (1996:412) notes, time and space are among the most frequently grammaticalized situational dimensions in languages across the world. Linguistic structures referring to these dimensions are traditionally known as "deictic expressions". ${ }^{27}$ Common to all deictic expressions is a distinction between what is proximal vs. distal to the deictic center or origo. This deictic center is typically

26 Compare Auer $(1996: 6-7,8)$, who explicitly includes "the physical surroundings of the speech situation" as a relevant dimension of context. Cloran (1999: 178-180) notes that, linguistically speaking, the importance of the material situational setting may vary: in contexts where language is facilitating a non-verbal social activity, the material situational setting will be highly relevant. On the other hand, when language is largely constitutive of the activity (where, in other words, language is the activity), the material situational setting will be less relevant.

For an introduction to deixis in Ancient Greek, see Edmunds (2008) and Bonifazi (2014). 
the speaker, and the central time and place are typically the speaker's time and place of writing/speaking: as Levinson (1983: 63) notes, "deixis is organized in an egocentric way".

Scholars traditionally distinguish between "temporal" and "spatial" deixis: temporal deixis "concerns the encoding of temporal points and spans relative to the time at which an utterance was spoken (or a written message inscribed)" (Levinson 1983: 62), whereas spatial deixis "concerns the encoding of spatial relations relative to the location of the participants in the speech event" (Levinson 1983: 62). In Ancient Greek, these two categories are grammaticalized/lexicalized in verbs and adverbs. ${ }^{28}$ Verbs certainly are the more complex category: they can convey temporal deixis through the use of tense, as is the case in many of the world's languages (cf. Levinson 1983: 77, 2004: 114), with the imperfect and aorist conveying events anterior to the time of speaking, the present events simultaneous to the time of speaking, and the future ${ }^{29}$ events posterior to the time of speaking. ${ }^{30}$ Verbs can also convey spatial deixis: at the lexical level, verbs of motion such as come and go may reveal information about the interactants' relative position (see most recently Bartolotta 2017). Aspect, too, plays a role in spatial deixis, ${ }^{31}$ but in a more complex way: as several studies have shown (see e.g. Bakker 1997; Aerts 2014; Bentein 2016), the use of the imperfect for foregrounded events in narrative may signal a shift in point of view, ${ }^{32}$ the deictic center no longer being the narrator, but a (virtual) character actually witnessing the events.

28 Grammaticalization and lexicalization both involve the development of new forms, but with the former they are grammatical, whereas with the latter the forms have referential meaning. Scholars have observed that many of the processes involved in grammaticalization also feature in lexicalization: so, for example, bonding and coalescence (e.g. beside < by + side (grammaticalization); gospel > god + spell (lexicalization)). Lexicalization does not usually involve a shift to a different functional category, however. For further discussion and references, see e.g. Lehmann (2002); Brinton \& Traugott (2005).

29 Lyons (1977: 677) notes that "the future is not like the past from the point of view of our experience and conceptualization of time". Lyons (1977: 677-678) considers the future partly temporal, and partly modal.

30 There has been some debate about this point in Ancient Greek. See e.g. Porter (1989), who argues that Greek does not grammaticalize time in the Greek verb. Also note that there are many exceptions, e.g. the use of the future with imperatival meaning, the use of the present with futural meaning, the omnitemporal present, the gnomic aorist, etc. (cf. Levinson 2004: 115).

31 On the close connection between aspect and space, see Lyons (1977: 719).

32 Lyons (1977: 579) speaks of a “deictic projection". Compare also Bühler's (1934) distinction between demonstratio ad oculos and demonstratio ad phantasma. 
Temporal deictic expressions frequently occur in our sample texts. They include present and future verb forms in the indicative mood such as aksiô $\hat{u}$ men 'we consider' (P.Ryl. IV 624, l. 3), hếksō 'I will come' (P.Herm. 2, l. 26), diákeimai (P.Herm. 6, 1. 12) 'I am in a certain state', sumbếsetai 'it will happen' (P.Herm. 6, ll. 11-12, ll. 19-20), and katabếsei 'you will return' (P.Herm. 6, ll. 2425). Present-tense forms are also used for omnitemporal expressions, which can be found in three of the letters (P.Ryl. IV 624, P.Herm. 6 \& P.Herm. 5): so, for example, epei kai ho en tôi kammúein khrónos elákhistos òn polús tis kaì amétrētos toîs erôsi kai pothoûsi diaphaínetai 'since even the few moments of time spent in sleep seem immeasurably long to those who pine away with love' (P.Herm. 6, 1l. 8-10). Present and aorist infinitives that are the complement to verbs of hoping, wishing, etc. can have future-time orientation (cf. Bentein 2018a): so, for example, with eúkhomai 'I pray, wish': eúkhomai tês toiaútēs apallagênai epithumías 'I pray to be freed of this desire' (P.Herm. 6, ll. 10-11), eúkhomai ... soi ... dothênai tà grámmata 'I pray that the letters are given to you' (P.Herm. 5, ll. 3-4), and eúkhomai ... kat'ópsin se theásasthai 'I pray to see you face to face' (P.Herm. 2, ll. 3-4). Time adverb(ial)s occur less frequently in our texts: in P.Herm. 2, Anatolius twice refers to Pharmoûthi 'Pharmouthi' as being the current month (ll. 20, 28). In the same text, we also find the adverb nûn 'now' (P.Herm. 2, l. 13; cf. P.Herm. 6, l. 6).

Whereas P.Herm. 5 and P.Herm. 4 exclusively focus on present and futuretime events, the three other texts in our corpus do refer to past-time events, albeit to a limited extent. These past events are mostly expressed through imperfect and aorist indicative forms: so, for example, proeilómetha 'we elected' (P.Ryl. IV 624, l. 5), ên ... moi póthos 'I had a desire' (P.Herm. 6, l. 3), and apeîkhon 'they hindered' (P.Herm. 2, l. 7). The aorist participle can be used with reference to past events, too: so, for example, kataksiôthéntes 'having been deemed worthy' (P.Ryl. IV 624, l. 6) and katalimphthéntes 'having been left behind' (P.Ryl. IV 624, l. 10). In P.Herm. 6, a perfect tense form is used to refer to an event which happened in the past and has present relevance (potheinotéran tèn théan hèmîn empepoiéken 'it has made the sight of you more desirable', ll. 7-8). References to past-tense events can mostly be found in the first part of the letters, forming the basis for present beliefs/emotions and future events: in P.Herm. 2, for example, Anatolius writes to Sarapion that he wishes to speak with him face to face, but that he has been hindered from doing so on a number of occasions (apeîkhon propháseis '(certain) reasons prevented (me)', l. 7), including the illnesses of his daughter which some god caused (theôn tis paréskhe 'one of the gods caused', l. 9). He concludes that he will come in the nearby future. Iohannes and Leon start their letter to Theophanes with an interesting pasttense form: anagkaîon hēgēsámetha prosagoreûsaí se 'we considered it neces- 
sary to write to you' (P.Herm. 4, Il. 3-4). Strictly speaking, the fact that Iohannes and Leon consider it important to write is valid at the time of writing, rather than before it, so we are dealing here with a so-called "epistolary aorist" (cf. Mandilaras 1973: 166-169), whereby the time of reading, rather than the time of writing, forms the temporal reference point.

Spatial deictic expressions are much less frequent than their temporal counterparts: Hephaestion, Horigines and Besodorus refer to "the city" in their letters (en têi pólei (P.Ryl. IV 624, l. 9), en pólei (P.Ryl. IV 624, l. 18), and katà tèn pólin (P.Herm. 6, l. 4)), and in Besodorus' letter there is also a reference to tè̀n patrída (P.Herm. 6, ll. 24-25), which Matthews translates as "your native city". ${ }^{33}$ That spatial deixis is much less frequently attested than temporal deixis is, of course, related to the fact that the latter is grammaticalized in the Greek verbal system, whereas the former is not. Only occasionally is a verb attested that lexicalizes spatial deixis, such as hêksō 'I will come' in P.Herm. 2 (l. 26), which gives us information about the relative positions of the sender and addressee, Anatolius and Sarpion respectively.

Next to temporal and spatial deixis, scholars recognize a third category of deictic expressions, namely person deixis, ${ }^{34}$ which "concerns the encoding of the role of participants in the speech event in which the utterance in question is delivered" (Levinson 1983: 62). Person(al) deixis thus concerns the interactants as speech participants, rather than their social characteristics, and as such is relevant to the contextual dimension of "setting". In Ancient Greek, as in many other languages, person deixis is grammaticalized in the person endings of verbs: the first person grammaticalizes the role of the speaker, whereas the second person that of the addressee. The third person is negatively defined with respect to the first and second person: it does not correlate with any positive participant role (cf. Lyons 1977: 638), referring as it does to persons/entities which are neither speaker nor addressee. In many languages, the picture is complicated by the fact that we can be used as a pluralis maiestatis, and you (pl.) as a form of address for the second person singular, but in Ancient Greek such usages only develop at a later time (cf. Bentein 2017a). Pronouns play an important role, too, when it comes to person deixis: Ancient Greek has a

33 In all of these cases, the article may be said to have a deictic function. On the definite article and deixis, see Lyons (1977:646-657). Note that in SFL, the article in all its uses is called "deictic" (see e.g. Halliday \& Matthiessen 2014: 367).

34 Others also recognize discourse deixis and social deixis as relevant deictic categories (see e.g. Levinson 1983: 82). Discourse deixis, however, falls under SFL's textual metafunction, rather than the interpersonal metafunction, and social deixis will be discussed later on (Section 3.3.1). 
set of personal, possessive and demonstrative pronouns which convey person deixis. The demonstrative pronouns are quite versatile: hóde and hoûtos are associated with the first and second person respectively, whereas ekeinos is a distal deictic, associated with the third person. They may also assume a pure discourse function (referring anaphorically or cataphorically), ${ }^{35}$ however, or function as spatial deictics, e.g. in their attributive function (as in "this book" vs. "that book"), in which case they indicate proximity to or distance from the speaker (compare Lyons 1977: 646).

In our sample texts, there are many personal deictic references to the sender and addressee(s), who together make up the speech participants. These deictic references are variously expressed: first and second person subjects are indicated in the main verb form; so, for example, eúkhomai 'I wish' (P.Herm. 6, l. 10), apoláboimi 'may I receive' (P.Herm. 6, l. 33), oîstha 'you know' (P.Herm. 2, 1. 3), hếksō 'I will come' (P.Herm. 2, 1. 26), etc. Non-nominative cases are expressed through personal pronouns, such as mou 'of me' (P.Herm. 2, ll. 1, 3, 30; P.Herm. 6, ll. 1, 4), se 'you' (P.Herm. 2, ll. 3, 7; P.Herm. 6, 1l. 11, 22, 27, 30, 31, 33), me 'me' (P.Herm. 2, l. 6), moi 'for me' (P.Herm. 2, l. 9; P.Herm. 6, 1l. 11, 16), and soi 'for you' (P.Herm. 6, ll. 20, 28, 32). Our texts also contain possessive pronouns such as emòn 'mine' (P.Herm. 2, ll. 4-5), sôi 'your' (P.Herm. 2, l. 14), and sêi 'your' (P.Herm. 6, l. 4). Unsurprisingly, in the two letters written by multiple senders, references are consistently in the first person plural: so, we find in P.Herm. 4 hēgèsámetha 'we thought' (l. 3), eukhómetha 'we wish' (l. 7), sun hèmin 'with us' (l. 9). Interestingly, in Hermodorus' letter to Theophanes (P.Herm. 5) we find an alternation between singular and plural references: Hermodorus starts his letter in the first person (gráphō 'I write' (1. 2)), but then shifts to the first person plural (hèmôn '(of) us' (1. 6); ekhōmen 'we have' (l. 7); hēmâs 'us' (1. 9); eukhómetha 'we wish' (l. 11), etc.). The same variation can be found in the final health wish: errôsthaí se polloîs khrónois eúkhomai ... kai apoláboimén se en tákhei 'I pray for your good health ... and may we receive you back speedily' (ll. 25-28). Presumably, this variation can be related to the fact that Hermodorus is writing in the name of the entire household.

Third-person deictic references are rare in our texts, which can be related to their monologic character: since senders are not directly communicating with their addressees, there is little occasion for deictic references to third persons. This is not to say that third persons do not appear in our letters: so, for example, in P.Herm. 5 and P.Herm. 4, various people send their greetings to the addressee, Theophanes. When verbs or pronouns refer to third persons, however, they do deixis and linguistic means used for textual cohesion (anaphora/cataphora). 
so anaphorically, rather than deictically (for example, hugiaínousi kai tà déonta práttousin 'they are in good health and fulfilling their obligations' (P.Herm. 5, ll. 17-18); taútas 'these' (P.Herm. 2, l. 9)).

\subsubsection{Stance}

Stance, too, is encoded at many levels of linguistic structure, which provides an indication of the "privileged role in the constitution of social life" (Ochs 1996: 420) stance has. Du Bois (2007:163) offers the following, very general, definition of stance:

Stance is a public act by a social actor, achieved dialogically through overt communicative means, of simultaneously evaluating objects, positioning subjects (self and others), and aligning with other subjects, with respect to any salient dimension of the sociocultural field.

Several types of stance ("stance acts") are typically distinguished, although no consensus exists on how many should be recognized (cf. Du Bois 2007: 144145). The most familiar distinction is that between "epistemic" and "affective" stance, which I will also refer to below. Specifically in the tradition of Systemic Functional Linguistics, another, related distinction has been made. In their work on appraisal, Martin \& White (2005) recognize three major domains, which they call "Attitude", "Graduation", and "Engagement". In what follows, we see that Attitude and Graduation are closely related to affective stance, whereas Engagement is related to epistemic stance.

\subsubsection{Epistemic stance}

Ochs (1996:410) defines epistemic stance as follows: "epistemic stance refers to knowledge or belief vis-à-vis some focus of concern, including degrees of certainty of knowledge, degrees of commitment to truth of propositions, and sources of knowledge, among other epistemic qualities". This definition can be compared to Martin \& White's (2005) definition of Engagement, ${ }^{36}$ which also emphasizes the importance of taking a position vis-à-vis some point of concern (94):

36 As Martin \& White (2005: 40) note, Engagement is in many respects similar to the notion of evidentiality (on which, see e.g. Chafe \& Nichols 1986). Martin \& White's proposal is more socially oriented than traditional accounts of evidentiality, however. Inspired by Bakhtin's dialogism, Martin \& White (2005: 99-100) make a basic distinction between "monoglossic" utterances, which do not make reference to other voices and alternatives, and "heteroglossic" ones, which do make reference to such voices and alternatives. 
The framework groups together under the heading of "Engagement" all those locutions which provide the means for the authorial voice to position itself with respect to, and hence to "engage" with, the other voices and alternative positions construed as being in play in the current communicative context.

As shown in Table 3, Martin \& White (2005:102) distinguish between four major types of Engagement, which can be divided into two broad categories, according to whether they are dialogically expansive or dialogically contractive in their intersubjective functionality. To be more specific, they argue that whereas Entertain and Attribute allow for dialogically alternative positions and voices, Disclaim and Proclaim challenge, fend off or restrict the scope of these positions and voices.

In Ancient Greek, as well as in other languages, epistemic stance/Engagement is realized by a diverse number of linguistic structures (cf. Van Rooy 2016): most importantly, these include particles (e.g. án, poú 'perhaps'; dé 'certainly'), conjunctions (e.g. hóti/hōs/háte 'because'), adverbs (e.g. tákha/ísōs 'perhaps'; dèladé 'clearly'), mood (e.g. the optative, the imperative), modal verbs and modal attributes (phaínetai/dokeî 'it seems'; sumphéron estí 'it is beneficial'), and mental state predicates (e.g. nomizó 'I believe'; oîda 'I know') and their complementation structures (e.g. finite vs. non-finite complementation structures).

Various linguistic structures belonging to Proclaim can be found in our sample texts, in particular the letters from Besodorus to Theophanes (P.Herm. 6) and Anatolius to Sarapion (P.Herm. 2): so, for example, we find mental state verbs such as pisteúo 'I trust', tharrô 'I have confidence', and oîstha 'I know': pisteúo ... kai tharrô hōs oudén ti aēdès oud' átopon sumbếsetai 'I have an explicit trust and confidence that nothing untoward or improper will happen' (P.Herm. 6, ll. 18-19), oîstha hōs eúkhomai 'you know that I wish' (P.Herm. 2, 1. 3); the modal attribute structure anagkaîon (esti) 'it is necessary': pareînai anagkaîon 'it is necessary to be present' (P.Herm. 2, l. 22); the particle ê mên 'truly' (P.Herm. 2, ll. 12-13); the conjunction háte with a participle, indicating "objective" cause: háte prostátên ónta emòn "because you are my patron" (P.Herm. 2, ll. 4-5); etc. That Proclaim plays a significant role in these two letters can be related to their function. Both Anatolius and Besodorus try to convince their addressee of a certain position: Besodorus that he is looking forward to the arrival of Theophanes, and Anatolius that he cannot come at the present time. In the other three letters, too, there are some elements indicating certainty from the part of the sender, such as the imperative euthúmei "be in good heart" (P.Herm. 5, 1. 15) and the expression anagkaîon hēgèsámetha "we considered it necessary" (P.Herm. 4, l. 3). 
TABLE 3 Taxonomy of Engagement (based on Martin \& White 2005)

\begin{tabular}{|c|c|c|}
\hline Disclaim & $\begin{array}{l}\text { "the textual voice positions itself as at odds with, or reject- } \\
\text { ing, some contrary position" (Martin \& White 2005: 97) }\end{array}$ & \multirow{2}{*}{$\begin{array}{l}\text { Dialogically } \\
\text { contractive }\end{array}$} \\
\hline Proclaim & $\begin{array}{l}\text { "the textual voice sets itself against, suppresses or rules out } \\
\text { alternative positions" (Martin \& White 2005: 98) }\end{array}$ & \\
\hline Entertain & $\begin{array}{l}\text { "the authorial voice represents the proposition as but one } \\
\text { of a range of possible options" (Martin \& White 2005: 98) }\end{array}$ & \multirow[b]{2}{*}{$\begin{array}{l}\text { Dialogically } \\
\text { expansive }\end{array}$} \\
\hline Attribute & $\begin{array}{l}\text { "the textual voice represents the proposition as but one } \\
\text { of a range of possible options-it thereby entertains or } \\
\text { invokes these dialogic alternatives" (Martin \& White 2005: } \\
99 \text { ) }\end{array}$ & \\
\hline
\end{tabular}

At the same time, another type of epistemic stance can also be found in our sample texts, which Martin \& White (2005) refer to as Entertain. ${ }^{37}$ To be more specific, all of our texts contain frequent references to wishes, which are either expressed through the optative (eié 'may it be' (P.Herm. 6, l. 22; P.Herm. 5, 1. 9), apoláboimi 'may I receive' (P.Herm. 6, l. 33), apoláboimen 'may we receive' (P.Herm. 5, ll. 27-28), lúseien 'may they remove' (P.Herm. 2, l. 10), páreien 'may they be present' (P.Herm. 2, 1. 31)), or through psychological verbs such as eúkhomai 'I pray, wish' and elpizō 'I hope' (eúkhomai ... apallagênai 'I wish to be freed' (P.Herm. 6, 1.11), eukhómetha kai elpizomen teúksesthai 'we wish and hope to receive' (P.Herm. 5, ll. 11-12), eukhómenoi ... dothēnai tèn epistolến 'praying that the letter is given' (P.Herm. 4, ll. 4-6), eúkhomai ... kat'ópsin se theásasthai 'I wish to see you face to face' (P.Herm. 2, ll. 3-4)). Such expressions can be situated in between 'epistemic' and 'affective' stance: when we consider them from the point of view of epistemic stance, we are not primarily interested in the specific feeling that is expressed, but rather in the fact that the speaker considers

37 Martin \& White (2005:108) note with respect to Entertain that "the primary function ... of such modalising locutions is to make allowances for, and hence to make space for, alternative voices and value positions in the ongoing colloquy within which the text is located". At the same time, they recognize that the extent to which certain propositions may be problematic for the intended addressee "will vary under certain co-textual conditionings" (2005: 109). In our texts, it does not seem to be the case that much dissent is being anticipated. 
the realization of the event as a possibility, rather than as a certain fact. Next to these wish-expressions, it is also worth referring to the use of the mental state predicate hègoumetha 'we thought' (P.Ryl. IV 624, l. 15) and the use of the particle án with the verb forms phulaksaimetha 'we would guard' (P.Ryl. Iv 624, l. 28) and eîkhon 'I would have' (P.Herm. 6, l. 27).

\subsubsection{Affective stance}

Next to epistemic stance, scholars have recognized a second major type of stance, that is, affective stance. As Ochs \& Schieffelin (1989:22) note, the need to express and assess affect is a fundamental human need, to which languages of the world are responsive: "affect permeates the entire linguistic system. Almost any aspect of the linguistic system that is variable is a candidate for expressing affect". Ochs (1996) provides the following definition of the notion: "affective stance refers to a mood, attitude, feeling, and disposition, as well as degrees of emotional intensity vis-à-vis some focus of concern".

Ochs \& Schieffelin (1989:14-15) make a basic distinction between two types of affective markers: affective specifiers, which indicate the nature of the affect, and affective intensifiers, which indicate the intensity of the affect. This distinction strongly resembles that made by Martin \& White (2005) between "Attitude" ( affective specifiers) and "Graduation" ( affective intensifiers) which I mentioned earlier. For Martin \& White (2005: 39), Attitude is the focal domain of APPRAISAL, Engagement and Graduation constituting distinct resources. Attitude itself involves three semantic regions, corresponding to what are traditionally called emotion, ethics and aesthetics. In Martin \& White's (2005) terminology, the emotive dimension, concerning positive and negative feelings, is called "affect", the ethic dimension, dealing with attitudes towards behavior, is called "judgment", and the aesthetic dimension, involving evaluations of semiotic and natural phenomena, is called "appreciation".38

In Ancient Greek, various linguistic structures express affective stance, Attitude in particular: adjectives play an important role (e.g. makários 'blessed', ekhthrós 'hateful'), but affective meanings can also be expressed through subjective verbs (e.g. miséó 'I hate', pothéō 'I desire'), nouns (e.g. makariótēe 'happiness', pénthos 'sorrow'), adverbs (e.g. dikaíōs 'rightfully', kalôs 'well'), and interjections (e.g. oímoi 'ah me', pópoi 'oh my!'). ${ }^{39}$ In general, it seems to be the case

$38 \quad$ Martin \& White (2005) consider affect to be central within the domain of Attitude.

39 See most recently Nordgren (2015), who subdivides interjections on the basis of four central emotions (pain, lamentation, surprise, and joy). 
that the expressions for affective stance are more lexical in nature than those for epistemic stance, which tend to be more grammatical in nature. ${ }^{40}$

Linguistic expressions indicating Attitude are omnipresent in our sample texts. Most of these are emotive, indicating positive affect. So, for example, we find expressions indicating happiness with a certain situation, including nouns such as holoklèrías '(concerning your) health' (P.Ryl.Iv 624, l. 10), hēdoné 'pleasure' (P.Ryl. IV 624, l. 27), kharâs '(with) joy' (P.Herm. 6, l. 24), and sōtērían 'well-being' (P.Herm. 5, l. 9); verbs such as kêdesthai 'to watch over' (P.Ryl. Iv624, l. 16), phrontízein 'to care for' (P.Ryl. Iv 624, l. 16), hēsthô 'I enjoy' (P.Herm. 6, l.18), apolaúein 'to enjoy' (P.Herm. 5, l. 10); and participles such as euphrainōn 'being happy' (P.Herm. 5, 1. 2), hugiainonti '(to you) being in good health' (P.Herm. 5, l. 3), and euthumoûnti '(to you) being in good spirit' (P.Herm. 5, l. 3). There are only two texts which overtly display negative affect. In Besodorus' letter to Theophanes (P.Herm. 6) we find many words which betray a certain desire and anxiety: we find adjectives such as potheinotéran 'more desirable' (l. 7), amétrētos 'immeasurable' (1. 9), makròn 'long' (l. 13), epimelès 'of concern' (l. 16), euktaîon 'prayed for' (1. 16); verbs such as pothoûsi 'for those who desire' (1. 9), páskhōn 'suffering' (l. 10), apallagênai 'to be released' (l. 11); and nouns such as póthos 'longing for' (l. 3), epithumías '(of) desire' (l. 11), and érgon 'a task' (l. 13). In Anatolius' letter to Sarapion (P.Herm. 2), there are a couple of expressions relating to antipathy and a bad physical state, such as nósoi 'illnesses' (1. 9) and kat' epếreian 'haughtily' (1. 10), but these are less prominent.

Next to expressions indicating affect, our texts also contain several expressions indicating judgment and appreciation. So, for example, we find khárin epistámetha 'we are grateful' (P.Ryl. IV 624, l. 5), kataksiōthéntes 'having been deemed worthy' (P.Ryl. IV 624, l. 6), pántōn diaphéron hēgoúmetha eînai érgon 'we consider this to be a duty that excels all others' (P.Ryl. IV 624, ll. 14-15), patròs agathoû '(of) a good father' (P.Ryl. IV 624, l. 17), oudèn gár estin oút' enti-

40 Diminutives might be considered one form of (positive) affect specifier that is grammatically encoded in Ancient Greek. Some other grammatical means mentioned by Ochs \& Schieffelin (1989: 15), such as voice, affixes and determiners, do not seem to play a role in Ancient Greek. Kuno (1987: 203-270) discusses various syntactic phenomena, such as the use of possessive noun phrases, reflexives, topicalization, and passivization, which do occur in Ancient Greek, in terms of a "camera angle", showing closer affinity with one participant than with another. She uses the term "empathy" for these phenomena. Stankiewicz (1964: 249) notes that "in various languages of the world we find phonetic features, such as palatalization, aspiration or glottalization, to be invested not with distinctive, but with emotive functions". For Ancient Greek, the issue of expressive phonemes constitutes a largely unexplored area of research, so I go no further into it here. 
móteron out' iskhuróteron 'for there is nothing more precious or more powerful' (P.Herm. 6, l. 14), tôn eulógōn dé esti 'it is right' (P.Herm. 5, ll. 4-5), anagkaîon 'necessary' (P.Herm. 4, l. 3), aparaitēton 'exacting' (P.Herm. 2, l. 12), and harmóttousan 'fitting' (P.Herm. 2, l. 13).

Martin \& White (2005) recognize the fact that Attitude also involves gradable meanings, a dimension they refer to with the term "Graduation" (compare Labov 1984 on "intensity"). They recognize two subcategories of Graduation: focus, which concerns Graduation according to prototypicality (e.g. a real father, a true friend), and force, which concerns Graduation according to intensity or amount (e.g. very lonely, more probable). In Ancient Greek, such gradable meanings are typically expressed by means of adverbs (e.g. mâllon 'more', liên 'very much'), focus particles (e.g. ge), quantifiers (e.g. pâs/hóstis 'everyone'), adjectives (e.g. polús 'much'), augmentatives (e.g. hupérkalos 'exceedingly beautiful', hupérēdus 'exceedingly sweet'; including also comparatives and superlatives) and diminutives (e.g. deltídion '(little) book', paidárion '(little) child').41 Martin \& White (2005: 37) note that "in general there seem to be more resources for turning the volume up than for turning it down", which seems to be true for Ancient Greek as well. Ochs \& Schieffelin (1989: 15) furthermore observe that cross-linguistically "it appears that there are more linguistic structures functioning as affective intensifiers than as affective specifiers", ${ }^{2}$ which seems harder to confirm with regard to Ancient Greek. ${ }^{43}$

There are noticeable differences between our sample texts in terms of Graduation. The letters from Hephaestion and Horigines (P.Ryl. IV 624) and from Besodorus (P.Herm. 6), are very rich in gradable meanings: most of the linguistic categories mentioned above are attested in just these two texts, including adverbs such as sphódra 'very much' (P.Ryl. IV 624, 1l. 2, 9; P.Herm. 6, l. 16) and pollákis 'often' (P.Herm. 6, l. 15); superlatives such as málista 'the most' (P.Ryl. IV 624, l.14), elákhistos 'very small' (P.Herm. 6, l. 9), tákhista 'very quick' (P.Herm. 6, l. 11), mégista 'the most' (P.Herm. 6, l. 17), hupsístōi '(to) the highest' (P.Herm. 6, 1. 26); comparatives such as entimóteron 'more precious' (P.Herm. 6, 1. 14) and iskhuróteron 'more powerful' (P.Herm. 6, l. 14); adjectives such as prôton 'first' (P.Ryl. Iv 624, l. 14) and polús 'much' (P.Herm. 6, l. 3); quantifiers such as hápanta

\footnotetext{
41 Repetition is also sometimes mentioned in this context (see e.g. Ochs 1996: 411).

42 Compare Labov (1984: 48), who notes that "there is no closed set of markers of intensity. Intensity is signaled by a large and miscellaneous class of devices, ranging from the most peripheral of prosodic variations to the most central categories of the grammar".

43 Note that Ochs \& Schieffelin (1989) also take into account a number of structures which are not prototypically associated with Graduation/affect intensification, such as repetition, word order, and the perfect tense (for the perfect tense, see Labov 1984: 46).
} 
(tòn khrónon) 'all (the time)' (P.Ryl. IV 624, l. 32) and pántas 'all' (P.Herm. 6, l. 32); and focus particles such as ge (P.Herm. 6, 1. 26). In the three other letters in our corpus, gradable meanings are less prominent. They are largely expressed through the quantifier pâs 'all' (e.g. pántes 'all' (P.Herm. 5, 1l. 21, 24), en pâsin 'in everything' (P.Herm. 4, l. 5)), although other categories are attested too: so, for example, we find adverbial expressions such as en tákhei 'soon' (P.Herm. 5, l. 10; P.Herm. 4, l. 7), pollákis 'often' (P.Herm. 2, ll. 5-6), and di' hólou 'entirely' (P.Herm. 2, l. 29).

That Attitude and Graduation play an important role in our sample texts, in particular those from Hephaestion and Horigines (P.Ryl. IV 624) and Besodorus (P.Herm. 6), has not escaped the attention of modern commentators. Choat (2009: 65), for example, notes with regard to Besodorus' letter that "[the text] employs rather more florid Byzantine rhetoric than others in the archive", although Rees (1968: 174) finds that "unlike most letters of the later Byzantine period, this one still seems to retain some trace of humanity and sincere affection, even if, like most of them, it conveys absolutely no news at all". Matthews (2006: 25) has underlined the rhetorical character of both texts: he draws attention to the "quasi-erotic intensity of Besodorus' language" in the first part of the letter, focusing as it does on friendship and the pains of absence, and notes that it has a rhetorical goal, namely to amplify the urgency of the inquiries in the second part. Matthews (2006: 28) stresses the same rhetorical purpose for Hephaestion and Horigines' letter, noting that "[Theophanes'] sons veil their subject matter behind a display of traditional rhetorical postures".

\subsection{Indirect indexicality \\ 3.3.1 Social identity}

Social identity, as Ochs (1996:410) defines it, is a broad concept: it includes not only social roles (e.g. doctor, teacher, coach), but also relationships (e.g. kinship, friendship), group identity (e.g. gender, class, ethnicity), and social rank (e.g. titled vs. untitled persons), among others (compare Van Dijk 20o9: 76 77). A basic distinction that can be made in this regard is between absolute vs. relational social identity (cf. Levinson 1983: 90): absolute social identity information concerns matters such as sex, gender, age, etc., whereas relational social identity information concerns participant roles and relations.

William Labov and his followers famously showed that language can be consistently related to such meso- and macro-social categories, thus establishing the discipline of (variationist) sociolinguistics (see e.g. Labov 2001). To be more specific, they showed that linguistic structures at all levels-phonological, orthographic, morphological, syntactic, and lexical-can carry indexical values. Crucially, such linguistic structures are non-referential indexicals, mean- 
ing that (a) they are not grammaticalized/lexicalized for these functions, and (b) they do not index one specific social value, or in other words, there is a relationship of non-exclusivity (especially the latter fact seems to have been forgotten from time to time) ${ }^{44}$ In the latter context, Eckert has recently introduced the notion of an "indexical field", that is "a constellation of meanings that are ideologically linked” (2008: 464). In Eckert's (2003: 41, 2008: 454) view, linguistic variables have an abstract and rather heterogeneous "indexical potential".

That social identity is indirectly indexed constitutes an interesting difference with what we have seen for social parameters such as setting/scene, epistemic stance and affective stance. Ochs (1996: 413) notes that indirect indexicality constitutes common practice across the languages of the world: "social identity is rarely grammaticized or otherwise explicitly encoded across the world's languages". Interestingly, though, referential indexes seem to be far less frequent than non-referential indexes.

With regard to Post-classical Greek, scholars have drawn attention to the association that exists between linguistic (especially morpho-syntactic) structures such as particles, complementation patterns and complementizers, moods, cases, relative clause types, word order, orthographic variants, etc., and contextual parameters such as (in)formality, social status, text type, agentive role, gender, etc. (for further discussion, see Browning 1983; Willi 2003, 2010, 2017; Horrocks 2007, 2010; James 2008; Bentein 2015, 2017b; Bentein \& Bagriacik 2018, among others). Even though such linguistic structures signal social identity indirectly, certain associations between language and social context seem to be partly motivated, a point which I elaborate further in Section 4. As for our sample texts, various linguistic structures can be found which index a higher social context. Such structures include wish and potential optatives such as phulaksaímetha ... án 'we would guard' (P.Ryl. Iv 624, 28), eiê 'may it be' (P.Herm. 6, l. 22; P.Herm. 5, l. 9), apoláboimi 'may I receive' (P.Herm. 6, 1. 33), apoláboimen 'may we receive' (P.Herm. 5, ll. 27-28), lúseien 'may they remove' (P.Herm. 2, 1. 10), and páreien 'may they be present' (P.Herm. 2, 1. 31); particles such as toigaroûn 'well then' (P.Herm. 2, l.12), ê mến 'truly' (P.Herm. 2, ll. 12-13), te ... kaí 'and' (P.Ryl. IV 624, l. 5; P.Herm. 6, ll. 5, 31; P.Herm. 5, l. 14; P.Herm. 2, ll. 23-24, 25-26), toínun 'so' (P.Herm. 6, 1. 10), and ge (P.Herm. 6, 1. 26); hốs as a preposition with the accusative and as a complementizer, as in tharrô hōs oudén ti aèdès oud' átopon sumbếsetai 'I trust that nothing untoward or improper will happen' (P.Herm. 6, l. 19), oîstha hōs eúkhomai 'you know that I wish' (P.Herm.

44 As Eckert (2003: 47) notes, "common practice views variables as directly indexing social categories". Van Dijk (2009: 4) speaks about a "determinist fallacy". 
2, 1. 3), and tês hōs se apheíkseōs (l. aphíkseōs) 'the arrival to you' (P.Herm. 2, 1. 7); nominal sentences such as érgon kai makròn eipein 'they are laborious and long to explain' (P.Herm. 6, l. 13) and pareînai anagkaîon 'it is necessary to be present' (P.Herm. 2, 1. 22); future and perfect forms such as empepoíēken 'it has made' (P.Herm. 6, l. 8), sumbēsetai 'it will happen' (P.Herm. 6, ll. 11-12, 19-20) and teúksesthai 'to receive' (P.Herm. 5, l. 12); and ov word order in complement structures such as phrontizein ... didáskei 'it teaches to take care of' (P.Ryl. IV 624, l. 16), matheîn ... boúlomai 'I want to learn' (P.Herm. 6, l. 30), horân eukhoménois 'for us who pray to see' (P.Herm. 6, ll. 7-8), and ópsei theōreîn ... hoîós t' ên egố 'if I could see' (P.Herm. 6, ll. 27-28).

Next to these morpho-syntactic structures, reference can also be made to the high number of expressions in our letters which are otherwise unattested or unusual in documentary texts, and which partly go back to Classical literary authors. ${ }^{45}$ This includes nouns such as amoibế 'recompense' (P.Ryl. IV 624, l. 3), hestía 'home' (P.Ryl. IV 624, l. 27), póthos 'desire' (P.Herm. 6, l. 3), epipháneia 'appearance' (P.Herm. 6, 1. 4), thumēdía 'pleasure' (P.Herm. 5, 1. 7), euphrosúnē 'gladness' (P.Herm. 5, l. 11), leitoúrgēma 'obligation' (P.Herm. 5, ll. 19-20), prostátēs 'patron' (P.Herm. 2, l. 4), hieromēnía 'the sacred month' (P.Herm. 2, 19); adjectives such as amétrētos 'immeasurable' (P.Herm. 6, l. 9), euktaîos 'desirable' (P.Herm. 5, l. 8), aksiágastos 'admirable' (P.Herm. 2, l. 5); verbs such as philopeustéo 'to inquire' (P.Ryl. IV 624, l. 10), eneudokiméó 'to enjoy a good reputation' (P.Ryl. Iv 624, l. 17), kammúó 'to sleep' (P.Herm. 6, l. 8), diakrázō 'to raise one's voice' (P.Herm. 6, l. 18), euphraínō 'to rejoice' (P.Herm. 5, l. 2), eudaimonéó 'to be happy' (P.Herm. 2, l. 28); and collocations such as akribôs eidénai 'to gain exact knowledge' (P.Ryl. IV 624, l. 7) and theôn tis 'one of the gods' (P.Herm. 2, 1. 9). Orthographic deviations, which are very common in documentary texts, are virtually absent in our letters. Only three instances can be found: $\omega$ for 0 (diékrazōn 'I raised my voice' (P.Herm. 6, l. 18)), $\eta$ for v (hêmôn 'of us' (P.Herm. 5, l. 16)), ${ }^{46}$ and $\varepsilon ı$ for I (apheíkseōs 'arrival' (P.Herm. 2, l. 7)). It is worth noting that in some of our letters archaic spellings can be found, such as phuláttontos 'guarding' instead of the more common phulássontos (P.Herm. 2, l. 11) and harmóttousan 'fitting' instead of the more common harmózousan (P.Herm. 2, l. 13).

That such high-register structures can be found so frequently in our letters may come as a surprise, since all of them are informal, personal letters. As I noted above, however, features such as the ones discussed here carried a rather

\footnotetext{
45 Moscadi (1970: 97-98) notes that Plato is the most common source, but that there are also references to the attic orators and tragedians.

46 It is unclear whether this is a real mistake. Cf. fn. 10.
} 
abstract indexical potential. In our particular case, these features may be taken to indicate the value our writers (and their addressees) attached to classical education and culture, ${ }^{47}$ but even here intentions may have varied. In the case of Hephaestion and Horigines, for example, the intention may have been to impress Theophanes: Roberts (1945:105) has suggested that their letter should be thought of as some sort of display piece, showing off the good education Theophanes had provided for them. Other writers in our archive may have had literary ambitions, as suggested by Moscadi $(1970: 118,138)$ for Anatolius' and Besodorus' letters. There is only one exception to this general trend: the letter written by Iohannes and Leon (P.Herm. 4) contains few if any higher-register features, even if it does not contain any substandard language. When we compare it to other letters in our sample, and take into account that it was written by the same scribe that wrote Hermodorus' letter to Theophanes (P.Herm. 5), the linguistic difference is remarkable, and could, perhaps, be attributed to the fact that the senders are on less familiar grounds with Theophanes, or have a different cultural background altogether.

Although social identity is typically signaled indirectly, there are some exceptions. As is well known, Ancient Greek grammatically marks gender. For example, in P.Herm. 6, the forms páskhōn 'suffering' (1. 10), katorthốsanta 'having put to rights' (1. 23), and errōménon 'healthy' (1. 33) indicate the male gender of the sender or addressee. Ancient Greek also has an extensive system of forms of address and honorific epithets indexing social identity, relational social identity in particular. ${ }^{48}$ Such forms of address can also be found in our sample texts: Theophanes is addressed with deference ${ }^{49}$ by Hephaestion and Horigines (tôi kuríoi hèmôn kai despótēi 'to our lord and master' (P.Ryl. IV 624, 1. 1)), as is Sarapion by Anatolius (tôi despótēi mou 'to my lord' (P.Herm. 2, l. 1)). Theophanes is greeted with greater familiarity by Iohannes and Leon (agapètôi adelphôi 'to our beloved brother' (P.Herm. 4, l. 1)) and Besodorus (tôi despótēi mou kai adelphôi 'to my master and brother' (P.Herm. 6, l. 1)). ${ }^{50}$ Besodorus con-

47 Cf. Choat (2009: 75): "the 'circle' of Theophanes, in so far as the papyri of the archive document it, appears to have been diverse in its beliefs, bound together not so much by religion as by a shared high regard for a classical education and a knowledge of Theophanes" (emphasis added/кв).

48 On forms of address, see Dickey (1996), whose study does not extend, however, into Late Antiquity. For honorific epithets, see the older study by Hornickel (1930).

49 This is in agreement with what we find in the rest of the archive; cf. Rees (1968:165); Choat (2009: 46).

50 Dickey (2010), however, notes that kúrie and ádelphe "were highly conventionalized and could be applied both to inferiors and to addressees with whom the writer had no personal relationship". 
tinues to use forms of address such as ádelphe kúrie 'lord brother' (1l. 4 \& 23), ádelphe psukhês 'brother of the soul' (1. 31), and déspota ádelphe 'lord brother' (1. 33) throughout his letter. Next to forms of address and honorific epithets, onomastics should also be taken into account. Studies have shown that particular names carried social value: Keenan (1974), for example, has argued that the names Flavius and Aurelius functioned as status markers in Later Roman Egypt. In similar vein, scholars have drawn attention to the use of patronymics, matronymics and papponymics in Greek papyri and elsewhere to indicate formality (appearing as they do in petitions, contracts, and other formal documents) (cf. Smitherman 2014: 45; Bentein 2018b). In our texts, such forms are not added, in accordance with the informal character of our documents.

Whether forms of address, honorific epithets, and names should be considered referential or non-referential indexicals is a point of debate. On the one hand, they show considerable similarity to non-referential indexicals, in that they index social identity, and that they do this indirectly and non-exclusively. For example, there has been some discussion about whether the use of adelphós 'brother' (as in P.Herm. 6) may be taken as a sign of the fact that Theophanes was actually a Christian, rather than a pagan (cf. Choat 2009: 56, 6365 ). On the other hand, certain of these forms do show a tendency to become closely associated with one particular indexical value, that is, towards direct indexicality (on such lexicalization, see e.g. Dickey 2010: 328 ). As Hornickel (1930: 18) shows, there are honorific epithets which are exclusively used for certain groups: the honorific epithet kathosiōménos 'dedicated', for example, is always used in reference to soldiers. The same is true for agapètós 'beloved' (cf. P.Herm. 4, l. 1): even though agápé 'love' and its cognates could also be used in a pagan context, there are few if any clearly non-Christian usages in the papyri, as Choat (2009: 64) notes. In many languages, forms such as these have become completely lexicalized (compare Levinson 1983: 89-94 on social deixis).

\subsubsection{Social acts and activities}

Social acts and activities are another aspect of social context that can be expressed through language. Whereas social acts are simple instances of goaldirected behavior (e.g. a request, an offer, a compliment), social activities are more complex, fossilized instances of social behavior, containing at least two social acts; the latter are traditionally referred to with the term "genre" (e.g. storytelling, interviewing, giving advice etc.). ${ }^{51}$ As Ochs (1996: 413) notes,

$5^{1} \quad$ Genres have been studied quite heavily in SFL under the heading of "context of culture". See, among others, Ventola (1984, 1987); Hasan (1989); Eggins \& Martin (1997); Martin 
TABLE 4 Speech function and sentential mode

\section{Speech function Congruent realization Example}

$\begin{array}{lll}\text { Statement } & \text { Declarative } & \text { He is opening the door } \\ \text { Question } & \text { Interrogative } & \text { Is he opening the door? } \\ \text { Offer } & \text { Conditional } & \text { Could I open the door? } \\ \text { Command } & \text { Imperative } & \text { Open the door! }\end{array}$

these two situational dimensions are not typically lexicalized/grammaticalized across the languages of the world. There does seem to be a narrow relationship between social acts and sentential mode, as shown in Table 4, where four speech functions are distinguished, based on a proposal by Halliday \& Matthiessen (2014, e.g. 136).

As many scholars have recognized, however, there are also incongruent realizations for these different speech functions: a command, for example, can also be phrased as a question (as in "Can you open the door?"). ${ }^{52}$ As a result, one can hardly say that there is a direct relationship between speech function (social act) and sentential mode. Moreover, as Ochs (1996: 413) notes, a case could be made that these modes index epistemic stance, rather than social acts: the interrogative mode can be taken as a sign of epistemic uncertainty, for example, whereas the declarative mode can be taken as a sign of epistemic certainty.

Similarly, there are few linguistic structures which directly index social activities. As Willi (2010: 298) notes with regard to Ancient Greek, "many genres are ... not characterized by specific linguistic features". Willi (2010: 299) gives the example of text-initial all' hótan/hopótan/hopóte 'but when' (followed by kai tóte dế 'then') as a marker of oracular verse responses in Classical times. Whereas many of these responses indeed start in this way, such a beginning was not a necessary ingredient of verse oracles. A common alternative marker is the use of the imperative phrázeu/phrázeo/phrázou 'tell' (but again, not every text containing this imperative should be thought of as a verse oracle). Other features which are likely to occur in oracles (though not necessarily) are epic

(2001); Eggins (2004: 54-84); Martin \& Rose (2008). A point of debate has been the relationship between "genre" and "register": see e.g. Ventola (1984, 1987: 51-86).

$5^{2}$ Scholars working within Speech Act Theory refer to this difference by distinguishing between "locutionary" vs. "illocutionary" speech acts (cf. Austin 1962; Searle 1969). Illocutionary acts are then further subdivided into "assertives", "directives", "commissives", etc. 


\begin{tabular}{|c|c|c|}
\hline $\begin{array}{l}\text { Structural } \\
\text { part }\end{array}$ & $\begin{array}{l}\text { Structural } \\
\text { component }\end{array}$ & Formula \\
\hline \multirow[t]{2}{*}{ Opening } & Prescript & e.g. A to B khairrein 'greetings' \\
\hline & Proem & $\begin{array}{l}\text { e.g. eúkhomaí se hugiainein } \\
\text { 'I wish that you are well' }\end{array}$ \\
\hline \multirow[t]{3}{*}{ Body } & Opening & $\begin{array}{l}\text { e.g. thélō se ginốskein } \\
\text { 'I want you to know' }\end{array}$ \\
\hline & Middle & $\begin{array}{l}\text { e.g. kalôs àn poiésais } \\
\text { 'you would do well' }\end{array}$ \\
\hline & Closing & $\begin{array}{l}\text { e.g. toûto dè poiésas eukharistếseis hēmîn } \\
\text { 'having done this you will please us' }\end{array}$ \\
\hline \multirow[t]{2}{*}{ Closing } & Epilogue & $\begin{array}{l}\text { e.g. mì̀ oûn állōs poiésēeis } \\
\text { 'so do not act differently' }\end{array}$ \\
\hline & Postscript & e.g. érrōso 'farewell' \\
\hline
\end{tabular}

vocabulary and phraseology, the use of metaphors, a high incidence of compound epithets, an injunction formulated in the jussive infinitive, etc. (cf. Willi 2010: 300 ).

As social activities, genres do often show a tendency to develop into structured linguistic events (Eggins 2004: 58), displaying a limited number of "functional" or "constituent" stages ${ }^{53}$ (what is called the schematic structure of the genre), some of which may be obligatory, whereas others may be optional. Such constituent stages can be introduced by a limited set of (formulaic) words and phrases, some of which may be exclusive to a specific genre. With regard to letter-writing in the Post-classical period, for example, Klauck (2006: 42) has proposed the schematic structure shown in Table $5 \cdot{ }^{54}$

Our sample texts do not exactly correspond to what is proposed in Table 5 . While all of them can be said to have a tripartite structure in terms of an opening, body, and closing, several of the structural parts that are proposed, as well as the standard formulae, are missing. So, for example, only two of the let-

53 See e.g. Hasan (1989: 56). One optional element is also the iteration of a stage (see e.g. Hasan 1989: 63).

54 Cf. also White (1972), and see Nachtergaele (2015) for the use of formulaic phrases in letters. Note that during the Late Antique period the form of letters changes quite dramatically (Fournet 2009). 
ters, those of Hermodorus (P.Herm. 5) and Iohannes and Leon (P.Herm. 4) to Theophanes, have an explicit proem with a health wish (eúkhomai hugiainontí soi kai euthumoûnti dothênai tà grámmata 'I pray that my letter is given to you in good health and spirits' (P.Herm. 5, 1l. 3-4) and eukhómenoi hugiainontí soi kai en pâsin euthumoûnti dothênai tè̀n epistolên 'praying that the letter is given to you in good health, and in all respects in good spirits' (P.Herm. 4, ll. 46)). Formulaic phrases are absent from the letter body, which only in P.Herm. 4 can be attributed to the extremely short message (ll. 7-8). After the greetings, the same two letters, those of Hermodorus and Iohannes and Leon have the standard phrase errôsthaí se ... eúkhomai 'I pray for your health' (P.Herm. 5, 11. 25-26; P.Herm.4, 1l. 11-13). In his letter to Theophanes, Besodorus opts for the uncommon errōménon se apoláboimi 'may I receive you back in good health' (P.Herm. 6, l. 34). Anatolius, too, comes up with an original alternative in his letter to Sarapion: eudaimonoíes di' hólou ... kai theoipáreien soiprosphilêis 'may you enjoy everlasting happiness ... and may the gods attend you and be kindly' (P.Herm. 2, ll. 28-32). That both Besodorus and Antolius follow the established rules of the genre to a lesser extent, and come up with innovative phrases in their letters, may be taken as an index of social identity (cf. Coupland 2007: 16): these are two highly educated writers, who are on familiar grounds with their addressees. In the case of Anatolius, use of the phrase theoi páreien soi prosphileis 'may the gods attend you' also highlights his function as arkhiprophéteess 'chief prophet' of the old religion.

In Section 3, I have presented a relatively straightforward system of how social meaning is expressed in Ancient Greek, Post-classical Greek in particular: micro-social categories such as setting, epistemic stance, and affective stance are directly expressed through linguistic structures which have been lexicalized/grammaticalized for these functions, and which belong to a closed set of parts of speech. Meso- and macro-social categories such as social identity, social acts, and social activities, on the other hand, are indirectly expressed through linguistic structures which have not been lexicalized/grammaticalized for these functions, and which belong to an open set of parts of speech. Actual language use is not so straightforward, however: as Ochs (1996: 418) notes, "indexicality does not stop at one situational domain". In fact, "any situational dimension ... can in theory help to constitute the meaning of any other situational meaning" (Ochs 1996: 419). One example is indirect speech forms: these may not only mark epistemic stance (indirect knowledge), but 
also the social act of reporting and/or the authoritative status of the speaker vis-à-vis the proposition. Ochs (1996) proposes that we think of particular situational dimensions as linked to other situational dimensions through "socially and culturally constructed valences", of which members in all societies have knowledge. She notes that such a system of linguistic forms conveying multiple social meanings has multiple advantages: (a) it is highly efficient from the perspective of linguistic processing and acquisition, and (b) it allows speakers to exploit structural ambiguities in social meaning for strategic ends (cf. Ochs 1992: 340-341).

Which situational dimensions are linked to each other, and how such links come into being, is a fascinating but complex area of research. In recent years, sociolinguists have focused on the link that seems to exist between affective stance (at the micro-level) and social identity (at the meso/macro-level), noting that variationists' understanding of social context has been static and limited (Coupland 2007: 76 speaks of "sociological essentialism"), and needs to take into account micro-social meaning (cf. Coupland 2007: 5). For example, in a recent study, Kiesling (2009: 179) has stressed the centrality of stance, noting that "stancetaking is always a speaker's primary concern in conversation; even in speech events in which we might think stance is peripheral, it is in fact of central importance". For Kiesling and others, there is no clash between micro-social meaning on the one hand and meso-/macro-social meaning on the other: "local processes of meaning-making depend on the affordances that socially structured variation in some sense provides" (Coupland 2007:8). Kiesling (2009) gives the example of the American English address form dude: this not only indicates masculinity at the meso-/macro-social level, but also "cool solidarity" at the micro-social level. Other situational dimensions may be linked, too, though these have received less attention. Kress (1993: 174-175), for example, notes that deictic features indicating spatial/temporal distance may also be used to express social distance. Examples are the use of the English past tense ("I wanted to ask you") and the use of the demonstrative pronouns (e.g. "how is that throat" instead of "how is your throat"). In similar vein, Coupland (2007: 91-92) argues that frequent usage of personal deictic forms, indicating a lot of shared knowledge, is a "linguistic manifestation of small social distance".

For an example of the complex interrelationships between situational dimensions from Post-classical Greek, let me briefly draw attention to the use of linguistic structures such as particles, moods, and complementation patterns-elements which also frequently occur in our sample texts. As we have seen, these linguistic structures convey epistemic stance, indicating a position vis-à-vis a proposition ("Proclaim", "Entertain", etc.). Interestingly, however, many of these structures became increasingly obsolete (certain particles dis- 
appearing, complementation being restructured, the optative no longer being used), and came to be used as social identity markers (indicating education, social status, etc.). If, according to what is discussed above, stancetaking at the micro-level also plays a role in the use of these structures, then affective stance, epistemic stance, and social identity are all involved in the choice of such structures. In a recent study, I have argued that these different levels might actually provide conflicting motivations (cf. Bentein 2017b): for example, for reasons of informality, an author might opt for the use of hót $i$ 'that' with the indicative after a complement-taking verb such as elpizo 'hope', even though from the point of view of epistemic stance the accusative and infinitive should have been chosen (which, however, carries a formal overtone).

Scholars have also studied the relationship between stance and social identity from a diachronic point of view. Ochs (1992), for example, has suggested that linguistic structures never directly come to index social identity: indexical relations are first established between linguistic structures and affective stances, and in a next stage come to be related with certain social groups who are believed to be most likely to take such stances..$^{55}$ Ochs (1996: 341 ) refers to Japanese, where linguistic features associated with men's speech "coarsely intensify the force of an utterance", whereas features associated with women's speech "typically convey an affect of gentle intensity", both types originally being referential indexicals. For an example from Classical Greek, we might turn to Willi (2017), who observes that the active transitive perfect, which was a new formation in the Classical period, seems to have been particularly associated with oratory. He relates this to the fact that the perfect, through its stative nuance vis-à-vis the aorist, is suitable for the expression of lasting achievements (in other words, indicating a certain stance). This, as Willi (2017:276) notes, "predisposes the perfect for rhetorical exploitation in utterances and genres where such achievements, be they positive or negative, have to be highlighted to make the text effective", such as lawcourt oratory.

Whether this "original" stance is the same as the one that is evoked in later uses, and whether stance is always present when non-referential indexicals are used, as Kiesling (2009) seems to suggest, ${ }^{56}$ is a point worth investigating

55 Compare Kiesling (2009: 172): "I contend that stance is the main interactional meaning being created, and it is a precursor, or primitive, in sociolinguistic variation: that is, sociolinguistic variants are initially associated with interactional stances and these stances become in turn associated with a social group meaning in a community over time and repeated use".

$5^{6}$ For a more moderate position, see Coupland (2007: 112-115), who suggests that the expression of micro-/meso-/macro-social meaning depends on the "discursive frame": some contexts will evoke one type of social meaning more often than others. 
more in the future. Another point that needs further investigation is exactly how stance and social identity are linked: are we suggesting that all indirect indexicals indicating social identity were in origin direct indexicals indicating stance? ${ }^{57}$ Although, as we have seen, there is some evidence for such a view, I believe this is not necessarily always the case: I would argue that indirect indexicality of social identity is not necessarily semantically mediated, but may also be directly attributed to linguistic structures through certain cultural models. ${ }^{58}$ For example, I would hypothesize that the reason why archaic features are considered typical for higher social contexts in Post-classical Greek is because there is a cultural model (known as "Atticism") ${ }^{59}$ which considers (linguistic) archaism superior and preferential, and views it as elitist. ${ }^{60}$ In similar vein, one could argue that there is a second cultural model which values linguistic complexity, ${ }^{61}$ and views it as marking higher social contexts. ${ }^{62}$ Bentein \& Bagriacik (2018), for example, suggest that in Post-classical Greek internally headed relative clause formation may have been favored in higher social contexts because of its syntactic complexity. Other linguistic features may come to index social identity on the basis of yet another type of cultural model, which associates structural characteristics of one language with those of another language. The use of the periphrastic progressive or of kai-parataxis in the Septuagint and New Testament as forms of Jewish Greek may be mentioned in this context. ${ }^{63}$ Figure 1 represents in graph form these two different models.

The cultural models that are involved in the second model in Figure 1 are often ideologically infused. In order to better understand the workings of ideology, ${ }^{64}$ it is worth referring to the work of Silverstein $(1979,2003)$, who recognizes different types of indexicalities, distinguishing between "first-order" indexicality, "second-order" indexicality, etc., ${ }^{65}$ a distinction which I consider

57 Ochs (1993:289) seems to make this suggestion when she writes that "social identity is a complex social meaning that can be distilled into the act and stance meanings that bring it into being".

$5^{8}$ On the notion of "cultural model", see e.g. Geeraerts (2003).

59 On Atticism, see e.g. Kazazis (2007); Horrocks (2010).

6o On the link between conservatism and elitism, see e.g. Coupland (2007:32).

61 In practice, these two cultural models are very similar, since it is generally taken that the restructuring of the Greek language in the Post-classical period can be considered in terms of a "simplification" (see e.g. Dickey 2009: 154).

62 Compare Hodge \& Kress (1988: 109), who view syntactic complexity as a "transparent signifier".

63 On Jewish and Christian Greek, see e.g. George (2010).

64 On cultural models and ideology, see also Geeraerts (2003: 27).

65 Compare Labov's (1972: 237-238) distinction between "indicators", "markers", and "stereotypes". 
Model 1:
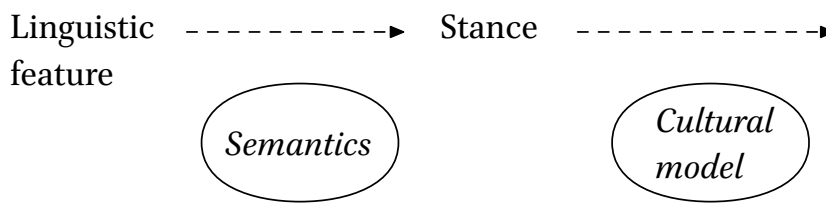

Social

identity

Model 2: Linguistic

Social

feature

identity

FIGURE 1 Models of linguistic features indexing social identity

particularly relevant for non-referential indexicals. Whereas first-order indexicality consists in the simple association by social actors of some linguistic structure with some meaningful social category such as age, class, gender, etc., second-order indexicality "is a metapragmatic concept, describing the noticing, discussion, and rationalization of first-order indexicality" (Milroy 2004: 167). As Milroy (2004: 167) notes, "it is these second-order indexical processes that emerge as ideologies". ${ }^{6}$ Participants' ideologies may consider perceived linguistic differences "as part of, and as evidence for, what they believe to be systematic behavioral, aesthetic, affective and moral contrasts among the social groups indexed" (Irvine \& Gal 2000: 37), thereby restructuring and distorting relationships between the linguistic structure and the social group. Irvine \& $\mathrm{Gal}$ (2000) distinguish between three important semiotic processes in this regard, which they call "iconization" (the interpretation of a linguistic form as a reflection of a social group's inherent nature or essence), "fractal recursivity" (the projection of an opposition, salient at some level of relationship, onto some other level), and "erasure" (the rendering of some persons or activities, or sociolinguistic phenomena, as invisible). A good example of iconization and fractal recursivity in Post-classical Greek is the language of the New Testament. As is commonly known, the New Testament is (largely) written in lower-register Greek. Subsequent commentators, such as Tatian, have commented on the sim-

66 Silverstein (1979: 193) offers the following definition of linguistic ideology: "sets of beliefs about language articulated by users as a rationalization or justification of perceived language structure or use". Some work has been done on ideology in the framework of Systemic Functional Linguistics. Martin (1992: 496) has argued that it should be conceptualized as another higher-level extra-linguistic communicative plane, above context of situation (register) and context of culture (genre). Banks (2009), however, has suggested that it may be necessary to reconsider the place of ideology in the Systemic Functional model. 
plicity of New Testament Greek, comparing the Greek of the early Christians to "fishermen's language" (iconization) and thus establishing a clear difference between pagans and Christians (fractal recursivity). ${ }^{67}$ It is interesting to note that such ideologies can also contribute to language change, for example through hypercorrections, which betray a sense of insecurity vis-à-vis a hegemonic standard. Kazazis (2007: 1208), for example, notes that in Atticistic texts even outright bizarre syntactic constructions are common, such as the optative in conditional clauses normally introduced by eán 'if' with the subjunctive, or the dative of time instead of the genitive of time.

Even if indirect indexicals may receive their social identity meaning on the basis of characteristics other than semantics, it is still worth paying attention to the role of stance at the micro-level. As mentioned above, Atticistic authors favored a puritan view of language in order to promote their elitist identity, but in other texts archaic features may be used to convey a rather different stance. Lee (1985), for example, finds that in the New Testament linguistic structures which are associated with formality, such as vocative $\hat{o}$ 'O!', the particle oûn 'so', the future tense, etc. are used specifically in the words of Jesus. One could hypothesize that the authors of the gospels did so in order to take a particular stance on Jesus towards their audience, marking, for example, his importance, his leadership, his moral qualities, etc. ${ }^{68}$ In similar vein, one could say that the senders of our sample texts had different motives to use archaic linguistic features. For example, Anatolius may have done so in order to present himself as an exponent of the old religion to Sarapion, whereas Besodorus may have done the same to present himself as an exponent of the new religion to Theophanes. Obviously, such considerations must remain speculative, especially in the case of Besodorus.

In this study, I have tried to develop an integrated approach towards the analysis of social meaning in Ancient Greek, Post-classical Greek in particular. Previous works have achieved significant progress in elucidating the social relevance of language, but so far, a more holistic, integrated perspective has been missing.

67 The example might also illustrate erasure, in that Tatian ignores the heterogeneity of Christian writers/discourse.

68 Cf. Lee (1985: 26), who notes that such features may have been introduced in the New Testament "out of a natural desire for the dignity of the speaker to be reflected in his language". 
I have argued that the theory developed by Michael Halliday and his followers provides a useful starting point for this type of discussion, because it distinguishes social meaning from two other types of meaning, and explicitly connects these different types of meaning to the social context. I have argued that in order to achieve a more comprehensive account of social meaning, however, it is necessary (a) to combine the framework with a typology of how signs signal meaning, distinguishing between referential vs. non-referential indexicals, and (b) to include micro-level social aspects in the theory, recognizing setting and stance as relevant contextual levels, next to social identity and social acts and activities. Building on previous work by Eleanor Ochs, I have shown that interesting correlations exist between different types of indexicals and aspects of the social context: micro-level social meanings such as setting and epistemic/affective stance are typically signaled through referential indexicals, which are grammaticalized/lexicalized and therefore exclusively used for these functions, whereas meso- and macro-level social meanings are typically signaled through non-referential indexicals, which are not grammaticalized/lexicalized and therefore non-exclusively used for these functions.

I have illustrated my approach by analyzing five sample texts form the fourth-century Theophanes archive, where linguistic features signaling all four contextual levels abound: temporal adverbs, verb tenses, verb endings, and personal pronouns signal the time of the speech event and the participants to it, hinting at the monologic character of our sample texts; particles, complementation patterns, and modal attribute structures on the one hand and comparatives/superlatives, adjectives, and adverbs on the other hand convey a specific stance, of the sender wanting to convince his addressee not only of a specific position, but also of his affection; complementizers, moods, particles, tense forms, nominal phrases, etc. indicate a higher social level, more specifically the value attached to classical education and culture; and particular (innovative) formulaic phrases show not only that we are dealing with private letters (rather than official letters, petitions or contracts), but also that we are dealing with educated writers who are on familiar grounds with their addressees. For reasons of presentation and clarity, I have not visually marked linguistic structures signaling social meaning in our two sample texts. If I would have done so, however, one would readily see the pervasiveness of social meaning in language. As Levinson (2004: 99) notes, the indexical system in language is embedded in a context-independent, symbolic system, "in such a way that the two systems produce a third that is not reducible to either".

Such small-scale observations on the social function of the Greek language in our sample texts may not come across as particularly innovative. The value of the framework which I presented here lies elsewhere, however: first, by high- 
lighting all relevant contextual dimensions, the framework challenges us to think about the social function of language in a more holistic fashion. Up until now, those who have studied social meaning in Ancient Greek have focused on specific aspects of it, social identity in particular. ${ }^{69}$ The challenge that lies before us is to look at the bigger picture, incorporating insights from other linguistic (sub)disciplines and extending the analysis to different linguistic levels (including, for example, the lexicon or formulaic phrases, next to syntax and morphology). As Martin (2000: 175) observes, "a virtual Pandora's box of issues awaits research ... a massive recontextualization of the linguistic enterprise". Second, the framework which I have presented here also makes it possible to study the complex nature of social meaning, by allowing for multiple levels of indexicality. As I have shown, indexical signs are pragmatically multifunctional, in that they can signal multiple aspects of social meaning at the same time. When it comes to Post-classical Greek, modal particles are a good example: these may not only signal epistemic stance, but also affective stance, and social identity. Much remains to be done in this second area, too: for example, we need to explore to what extent the different contextual levels can provide competing motivations for the choice of linguistic structures, or to what extent these different levels (stance and social identity in particular) are diachronically related.

The same questions could, of course, also be asked for other genres and periods of the Greek language, although the answers are likely to be different, to some extent, at least. The framework could also be applied to other languages: there is nothing language-specific to it, broadly speaking. Ultimately, I believe we must also have the courage to look beyond language, and to investigate how other semiotic resources such as handwriting, writing material, document format, etc. create social meaning, next to, and together with, language. As Eckert (2003: 47) notes, "variation does a tremendous amount of symbolic work, but language does not work on its own, and no linguistic variant works on its own". Choat (2009: 47), for example, has observed with regard to the personal letters in the Theophanes archive that they are remarkable for the quality of their handwriting, and that they even employ punctuation, a feature which is hardly ever found in private communications. The choice for these features is hardly coincidental, I believe, and further contributes to the social meaning conveyed by the sender to the addressee.

69 Compare Ochs (1996:417): "many pragmatic and anthropological linguistic studies of indexicality tend to focus on only one situational dimension associated with one set of linguistic forms". 


\section{Acknowledgments}

I want to thank two anonymous reviewers for their helpful comments on previous versions of this article. Parts of this article were presented at the Text-in-Context Workshop (Ghent, March 20, 2018) and at the conference $A$ Corpus and Usage-based Approach to Ancient Greek: From the Archaic Period until the Koiné (Riga, April 12-14, 2018). My work was funded by the Flemish Fund for Scientific Research (Grant Nr 12B7218N) and the European Research Council (Horizon 2020 research and innovation programme, Starting Grant $\mathrm{Nr}$ $756487)$.

\section{References}

Aerts, Simon. 2014. A Systemic Functional "three-dimensional" approach to aspect in Thucydides' Histories III. Symbolae Osloenses 88: 2-41.

Auer, Peter. 1996. Context and contextualization. In: Handbook of pragmatics, ed. by Jef Verschueren, Jan-Ola Östman, Jan Blommaert \& Chris Bulcaen, 1-19. Amsterdam: Benjamins.

Austin, John L. 1962. How to do things with words. Cambridge, MA: Harvard University Press.

Bakhtin, Mikhail. 1986. The problem of speech genres. In: Speech genres and other late essays, ed. by Caryl Emerson, Michael Holquist \& Vern W. MacGee, 6o-102. Austin, TX: University of Texas Press.

Bakker, Egbert J. 1997. Verbal aspect and mimetic description in Thucydides. In: Grammar as interpretation: Greek literature in its linguistic contexts, ed. by EgbertJ. Bakker, 1-51. Leiden \& New York: Brill.

Banks, David. 20o9. The position of ideology in a Systemic Functional model. Word 6o.39-63.

Bartolotta, Annamaria. 2017. On deictic motion verbs in Homeric Greek. Ancient Greek linguistics: new approaches, insights, perspectives, ed. by Felicia Logozzo \& Paolo Poccetti, 277-292. Berlin \& Boston: De Gruyter.

Bentein, Klaas. 2013. Register and the diachrony of Post-classical and Early Byzantine Greek. Revue Belge de Philologie et d'Histoire 91: 5-44.

Bentein, Klaas. 2015a. Minor complementation patterns in Post-classical Greek (IVIAD). A socio-historical analysis of a corpus of documentary papyri. Symbolae Osloenses 89: 104-147.

Bentein, Klaas. 2015b. The Greek documentary papyri as a linguistically heterogeneous corpus: The case of the katochoi of the Sarapeion-archive. Classical World 108:461484 . 
Bentein, Klaas. 2016. Aspectual choice and the presentation of narrative. An application to Herodotus' Histories. Glotta 92: 24-55.

Bentein, Klaas. 2017a. Politeness in pronouns: Third person reference in Byzantine documentary papyri. Philologus 161: 256-267.

Bentein, Klaas. 2017b. Finite versus non-finite complementation in Post-classical and Byzantine Greek. Towards a pragmatic restructuring of the complementation system? Journal of Greek Linguistics 17: 3-36.

Bentein, Klaas. 2018a. The loss of infinitival complementation in Ancient Greek: A case of diachronic ambiguity resolution? Glotta 94: 82-118.

Bentein, Klaas. 2018b. Expressing lineage in Roman and Late Antique petitions and contracts: A variationist perspective. The Journal of Juristic Papyrology 48: 1-35.

Bentein, Klaas \& Metin Bagriacik. 2018. On the third type of headed relative clause in Post-Classical and Early Byzantine Greek. Transactions of the Philological Society 116: 529-554.

Bonifazi, Anna. 2014. Deixis. In: Encyclopedia of Ancient Greek language and linguistics, ed. by Georgios K. Giannakis et al., 422-429. Leiden \& Boston: Brill.

Brinton, Laurel J. \& Elisabeth C. Traugott. 2005. Lexicalization and language change. Cambridge \& New York: Cambridge University Press.

Brown, Roger \& Albert Gilman. 1960. The pronouns of power and solidarity. In: Style in language, ed. by Thomas A. Sebeok, 257-276. Cambridge, MA: Technology Press of Massachusetts Institute of Technology \& New York: John Wiley \& Sons, Inc.

Browning, Robert. 1983. Medieval and Modern Greek. 2nd edn. Cambridge \& New York: Cambridge University Press.

Bucholtz, Mary \& Kira Hall. 2005. Identity and interaction: a sociocultural linguistic approach. Discourse Studies 7: 585-614.

Bühler, Karl. 1934. Sprachtheorie: Die Darstellungsfunktion der Sprache. Jena: G. Fischer.

Butt, David \& Rebekah Wegener. 2005. The work of concepts: context and metafunction in the Systemic Functional model. In: Continuing discourse on language: a functional perspective, vol. 2, ed. by Ruqaiya Hasan, Christian Matthiessen \& Jonathan J. Webster, 589-618. Bristol: Equinox Publishing.

Butler, Christopher S. 2008. The interpersonal function of language. In: Encyclopaedia of the linguistic sciences: Issues and theories, ed. by V. Prakāśam, 43-49. New Delhi: Allied Publishers.

Chafe, Wallace \& Johanna Nichols (eds.). 1986. Evidentiality: The linguistic coding of epistemology. Norwood, NJ: Ablex Publishing.

Choat, Malcolm. 20og. The public and private worlds of Theophanes of Hermopolis Magna. Bulletin of the John Rylands University Library of Manchester 88: 41-75.

Cloran, Carmel. 1999. Context, material situation and text. In: Text and context in Functional Linguistics, ed. by Mohsen Ghadessy, 177-210. Amsterdam: John Benjamins. 
Cook, Guy. 199o. Transcribing infinity. Journal of Pragmatics 14:1-24.

Coupland, Nikolas. 2001. Introduction: Sociolinguistic theory and social theory. In: Sociolinguistics and social theory, ed. by Nikolas Coupland, Srikant Sarangi \& Christopher N. Candlin, 1-26. Harlow \& New York: Longman.

Coupland, Nikolas. 2007. Style: language variation and identity. Cambridge \& New York: Cambridge University Press.

Dickey, Eleanor. 1996. Greekforms of address: From Herodotus to Lucian. Oxford: Clarendon Press.

Dickey, Eleanor. 2009. The Greek and Latin languages in the papyri. In: The Oxford handbook of papyrology, ed. by Roger S. Bagnall, 149-169. New York \& Oxford: Oxford University Press.

Dickey, Eleanor. 2010. Forms of address and markers of status. In: A companion to the Ancient Greek language, ed. by Egbert J. Bakker, 327-337. Malden, MA: WileyBlackwell.

Du Bois, John W. 2007. The stance triangle. In: Stancetaking in discourse: Subjectivity, evaluation, interaction, ed. by Robert Englebretson, 139-182. Amsterdam \& Philadelphia: John Benjamins.

Eckert, Penelope. 2003. The meaning of style. Texas Linguistic Forum 47: 41-53.

Eckert, Penelope. 2008. Variation and the indexical field. Journal of Sociolinguistics 12: 453-476.

Eckert, Penelope. 2012. Three waves of variation study: The emergence of meaning in the study of sociolinguistic variation. Annual Review of Anthropology 41: 87-100.

Edmunds, Lowell. 2008. Deixis in Ancient Greek and Latin literature: Historical introduction and state of the question. Philologia Antiqua 1: 67-98.

Eggins, Suzanne \& J.R. Martin. 1997. Genres and registers of discourse. In: Discourse as structure and process, vol. 1, ed. by Teun A. van Dijk, 230-256. London: SAGE Publications.

Eggins, Suzanne. 2004. An introduction to Systemic Functional Linguistics. 2nd edn. New York: Continuum.

Ellis, Jeffrey O. 1966. On contextual meaning. In: In memory of J.R. Firth, ed. by Charles E. Bazell et al., 79-95. London: Longmans.

Fournet, Jean-Luc. 20o9. Esquisse d'une anatomie de la lettre antique tardive d'après les papyrus. Correspondances. Documents pour l'histoire de l'Antiquité tardive, ed. by Roland Delmaire, Janine Desmulliez \& Pierre-Louis Gatier, 3-66. Lyon: Maison de l' Orient et de la Méditerranée-Jean Pouilloux.

Gal, Susan \& Judith T. Irvine. 1995. The boundaries of languages and disciplines: How ideologies construct difference. Social Research 62: 967-1001.

Geeraerts, Dirk. 2003. Cultural models of linguistic standardization. In: Cognitive models in language and thought. Ideology, metaphors and meanings, ed. by René Dirven, Roslyn Frank \& Martin Pütz, 25-68. Berlin \& New York: De Gruyter. 
George, Coulter H. 2010. Jewish and Christian Greek. A companion to the Ancient Greek language, ed. by Egbert J. Bakker, 267-280. Malden, MA: Wiley-Blackwell.

Gumperz, John J. 1982. Discourse strategies. Cambridge: Cambridge University Press.

Halliday, M.A.K. 1970. Language structure and language function. In: New horizons in linguistics, ed. by John Lyons, 140-165. Harmondsworth: Penguin.

Halliday, M.A.K. 1978. Language as a social semiotic: The social interpretation of language and meaning. Baltimore: University Park Press.

Halliday, M.A.K. 1991. Corpus studies and probabilistic grammar. In: English corpus linguistics: Studies in honour of Jan Svartvik, ed. by Karin Aijimer \& Bengt Altenberg, 30-43. London \& New York: Longman.

Halliday, M.A.K. \& Christian M.I.M. Matthiessen. 2014. Halliday's introduction to Functional Grammar. London: Taylor \& Francis.

Hasan, Ruqaiya. 1989. Part B. In: Language, context, and text, 2nd edn., ed. by M.A.K. Halliday \& Ruqaiya Hasan, 52-118. Oxford \& New York: Oxford University Press.

Hasan, Ruqaiya. 1999. Speaking with reference to context. Text and context in Functional Linguistics: Systemic perspectives, ed. by Mohsen Ghadessy, 219-328. Amsterdam \& Philadelphia: John Benjamins.

Hasan, Ruqaiya. 2001. Wherefore context?: The place of context in the system and process of language. In: Grammar and discourse: Proceedings of the International Conference on Discourse Analysis, ed. by Ren Shaozheng, William Guthrie \& I.W. Ronald Fong, 1-21. Macau: The Chinese University Press.

Hasan, Ruqaiya. 2009. Wanted: A theory for integrated sociolinguistics. In: Semantic variation: Meaning in society and in sociolinguistics, ed. by Jonathan J. Webster, $5^{-}$ 40. London \& Oakville: Equinox.

Hodge, Robert \& Gunther Kress. 1988. Social semiotics. Ithaca, NY: Cornell University Press.

Hornickel, Otto. 1930. Ehren- und Rangprädikate in den Papyrusurkunden: Ein Beitrag zum römischen und byzantinischen titelwesen. University of Giessen, doctoral dissertation.

Horrocks, Geoffrey. 2007. Syntax: From Classical Greek to the Koine. In: A history of Ancient Greek, ed. by Anastasios-Phoivos Christidis, 618-631. Cambridge \& New York: Cambridge University Press.

Horrocks, Geoffrey. 2010. Greek: A history of the language and its speakers, 2nd edn. Chichester \& Malden, MA: Wiley-Blackwell.

Hymes, Dell H. 1961. Functions of speech: An evolutionary approach. In: Anthropology and education, ed. by Frederick C. Gruber, $55^{-83}$. Philadelphia: University of Pennsylvania.

Irvine, Judith T. \& Susan Gal. 20oo. Language ideology and linguistic differentiation. In: Regimes of language: Ideologies, polities, and identities, ed. by Paul V. Kroskrity, 35-84. Santa Fe, NM: School of American Research Press. 
Jakobson, Roman. 1960. Linguistics and poetics. In: Style in language, ed. by Thomas A. Sebeok, 350-377. Cambridge, MA: Technology Press of Massachusetts Institute of Technology \& New York: John Wiley \& Sons, Inc.

James, Patrick. 2008. Complementary participles and infinitives with verbs of perception and declaration in the Roman and Byzantine documentary papyri. Cambridge University, doctoral dissertation.

Kazazis, John N. 2007. Atticism. In: A history of Ancient Greek: From the beginnings to Late Antiquity, ed. by Anastasios-Phoivos Christidis, 1200-1212. Cambridge \& New York: Cambridge University Press.

Keenan, James G. 1974. The names Flavius and Aurelius as status designations in later Roman-Egypt. Zeitschrift für Papyrologie und Epigraphik 13: 283-304.

Kiesling, Scott. 20o9. Style as stance: Can stance be the primary explanation for patterns of sociolinguistic variation? In: Sociolinguistic perspectives on stance, ed. by Alexandra Jaffe, 171-194. New York \& Oxford: Oxford University Press.

Klauck, Hans-Josef. 2006. Ancient letters and the New Testament: A guide to context and exegesis. Waco, Tx: Baylor University Press.

Knorr-Cetina, Karin \& Aaron V. Cicourel (eds). 1981. Advances in social theory and methodology. Toward an integration of micro- and macro-sociologies. Boston: Routledge \& Kegan Paul.

Kress, Gunther. 1993. Against arbitrariness: The social production of the sign as a foundational issue in Critical Discourse Analysis. Discourse and Society 4:169-191.

Kuiper, Koenraad. 20o9. Formulaic genres. Basingstoke \& New York: Palgrave Macmillan.

Kuno, Susumu. 1987. Functional syntax: Anaphora, discourse and empathy. Chicago: University of Chicago Press.

Labov, William. 1972. Sociolinguistic patterns. Philadelphia: University of Pennsylvania Press.

Labov, William. 1984. Intensity. In: Meaning, form and use in context: linguistic applications, ed. by Deborah Schriffin, 43-70. Washington, DC: Georgetown University Press.

Labov, William. 2001. Principles of linguistic change, volume 2: Social factors. Oxford \& Cambridge, MA: Blackwell.

Leckie-Tarry, Helen. 1995. Language and context. A functional linguistic theory of register. London \& New York: Pinter Publishers.

Lee, J.A.L. 1985. Some features of the speech of Jesus in Mark's Gospel. Novum Testamentum 27: 1-26.

Leech, Geoffrey N. 1981. Semantics: the study of meaning. 2nd edn. Harmondsworth \& New York: Penguin.

Lehmann, Christian. 2002. New reflections on grammaticalization and lexicalization. In: New reflections on grammaticalization, ed. by Ilse Wischer \& Gabriele Diewald, 1-18. Amsterdam \& Philadelphia:John Benjamins. 
Levinson, Stephen C. 1983. Pragmatics. Cambridge \& New York: Cambridge University Press.

Levinson, Stephen C. 2004. Deixis. In: The handbook of pragmatics, ed. by Laurence R. Horn \& Gregory L. Ward, 97-121. Malden, MA: Blackwell.

Lyons, John. 1977. Semantics. Cambridge \& New York: Cambridge University Press.

Mandilaras, Basil G. 1973. The verb in the Greek non-literary papyri. Athens: Ministry of Culture and Sciences.

Martin, R. 1992. English text: System and structure. Amsterdam \& Philadelphia: John Benjamins.

Martin, J.R. 200o. Beyond exchange: APPRAISAL systems in English. In: Evaluation in text:Authorialstance and the construction of discourse, ed. by Susan Hunston \& Geoff Thompson, 142-175. Oxford: Oxford University Press.

Martin, J.R. 2001. Language, register and genre. In: Analyzing English in a global context: A reader, ed. by Anne Burns \& Caroline Coffin, 149-166. London: Taylor \& Francis.

Martin, J.R. \& Peter R.R. White. 2005. The language of evaluation: Appraisal in English. Basingstoke \& New York: Palgrave Macmillan.

Martin, J.R. \& David Rose. 20o8. Genre relations: mapping culture. London \& Oakville: Equinox.

Matthews, John F. 2006. The journey of Theophanes: Travel, business, and daily life in the Roman East. New Haven: Yale University Press.

Milroy, James. 2001. Language ideologies and the consequences of standardization. Journal of Sociolinguistics 5: 530-555.

Milroy, Lesley. 2004. Language ideologies and linguistic change. Sociolinguistic variation: critical reflections, ed. by Carmen Fought, 161-177. New York: Oxford University Press.

Moore, Emma \& Robert J. Podesva. 2009. Style, indexicality and the social meaning of tag questions. Language in Society 38: 447-485.

Moscadi, Alessandro. 1970. Le lettere dell' archivio di Teofane. Aegyptus 50: 88-154.

Nachtergaele, Delphine. 2015. The formulaic language of the Greek private papyrus letters. Ghent University, doctoral dissertation.

Nordgren, Lars. 2015. Greek interjections. Syntax, semantics and pragmatics. Berlin \& Boston: De Gruyter.

Nuyts, Jan. 1989. On the functionality of language. Papers in Pragmatics 3: 88-129.

Ochs, Elinor \& Bambi Schieffelin. 1989. Language has a heart. Text 9: 7-25.

Ochs, Elinor. 199o. Indexicality and socialization. In: Cultural psychology: Essays on comparative human development, ed. by James W. Stigler, Richard A. Shweder \& Gilbert Herdt, 287-308. Cambridge \& New York: Cambridge University Press.

Ochs, Elinor. 1992. Indexing gender. In: Rethinking context: Language as an interactive phenomenon, ed. by Alessandro Duranti \& Charles Goodwin, 335-358. Cambridge \& New York: Cambridge University Press. 
Ochs, Elinor. 1993. Constructing social identity: A language socialization perspective. Research on Language and Social Interaction 26: 287-306.

Ochs, Elinor. 1996. Resources for socializing humanity. In: Rethinking linguistic relativity, ed. by John J. Gumperz \& Stephen C. Levinson, 407-438. Cambridge \& New York: Cambridge University Press.

Peirce, Charles S. 1933[1885]. Three kinds of signs. In: Collected papers of Charles Sanders Peirce, vol. 3, ed. by Charles Hartshorne \& Paul Weiss, 359-364. Cambridge, MA: Harvard University Press.

Porter, Stanley E. 2016. Systemic Functional Linguistics and the Greek language: The need for further modeling. In: Modeling Biblical language: Selected papers from the McMaster Divinity College Linguistics Circle, ed. by Stanley E. Porter, Gregory P. Fewster \& Christopher D. Land, 7-47. Leiden \& Boston: Brill.

Porter, Stanley E. 1989. Verbal aspect in the Greek of the New Testament. New York: Peter Lang.

Poynton, Cate. 1985. Language and gender: Making the difference. Geelong, Vic.: Deakin University Press.

Poynton, Cate. 1990. Address and the semiotics of social relations. University of Sydney, doctoral dissertation.

Poynton, Cate \& Alison Lee. 20o9. Debating appraisal: On networks and names. Making a difference: Challenges in applied linguistics, ed. by Honglin Chen \& Ken Cruickshank, 21-36. Newcastle-upon-Tyne: Cambridge Scholars.

Rees, Brinley R. 1964. Papyri from Hermopolis and other documents of the Byzantine period. London: Egypt Exploration Society.

Rees, Brinley R. 1968. Theophanes of Hermopolis Magna. Bulletin of the John Rylands Library 51: 164-183.

Roberts, C.H. 1945. A footnote to the civil war of A.D.324. Journal of Egyptian Archaeology 31: 113 .

Robinson, W. Peter. 2003. Language in social worlds. Oxford: Blackwell.

Searle, John R. 1969. Speech acts: An essay in the philosophy of language. London: Cambridge University Press.

Silverstein, Michael. 1976. Shifters, linguistic categories, and cultural description. In: Meaning in anthropology, ed. by Keith H. Basso \& Henry A. Selby, 11-55. Albuquerque, NM: University of New Mexico Press.

Silverstein, Michael. 1979. Language structure and linguistic ideology. The elements: $A$ parasession on linguistic units and levels, ed. by Paul R. Cline, William F. Hanks \& Carol L. Hofbauer, 193-247. Chicago: Chicago Linguistic Society.

Silverstein, Michael. 1985. Language and the culture of gender: at the intersection of structure, usage, and ideology. Semiotic mediation: Sociocultural and psychological perspectives, ed. by Elizabeth Mertz \& Richard J. Parmentier, 219-259. Orlando: Academic Press. 
Silverstein, Michael. 2003. Indexical order and the dialectics of sociolinguistic life. Language and Communication 23: 193-229.

Smitherman, Thomas. 2014. Patronymics. In: Encyclopedia of Ancient Greek language and linguistics, ed. by Georgios K. Giannakis et al., 45-46. Leiden \& Boston: Brill.

Sowa, John F. 20o1. Review of "Construing experience through meaning: a languagebased approach to cognition". Computational Linguistics 27: 140-145.

Stankiewicz, Edward. 1964. Problems of emotive language. In: Approaches to semiotics, ed. by Thomas A. Sebeok, 239-264. The Hague: Mouton.

Thompson, Susan \& Geoff Hunston. 200o. Evaluation: An introduction. Evaluation in text:Authorialstance and the construction of discourse, ed. by Susan Hunston \& Geoff Thompson, 1-27. Oxford \& New York: Oxford University Press.

Vandorpe Katelijn. 2010. History: Ptolemaic Egypt. In: A companion to Ancient Egypt. Vol. 1. State and Society, ed. by Alan B. Lloyd, 159-179. Chichester \& Malden, MA: Wiley-Blackwell.

Van Dijk, Teun A. 2008. Discourse and context. A sociocognitive approach. Cambridge: Cambridge University Press.

Van Dijk, Teun A. 2009. Society and discourse. How social contexts control text and talk. Cambridge: Cambridge University Press.

Van Rooy, Raf. 2016. The relevance of evidentiality for Ancient Greek: Some explorative steps through Plato. Journal of Greek Linguistics 16: 3-46.

Ventola, Eija. 1984. The dynamics of genre. Nottingham Linguistic Circular 13: 103-123.

Ventola, Eija. 1987. The structure of social interactions: A systemic approach to the semiotics of service encounters. London: F. Pinter.

White, J.L. 1972. The form and function of the body of the Greek letter. Missoula, MT: Society of Biblical Literature.

Willi, Andreas. 2003. The languages of Aristophanes. Oxford: Oxford University Press.

Willi, Andreas. 2010. Register variation. In: A companion to the Ancient Greek language, ed. by Egbert J. Bakker, 297-310. Malden, MA: Wiley-Blackwell.

Willi, Andreas. 2017. Register variation and tense/aspect/mood categories in Ancient Greek: Problems and perspectives. In: Variation and change in Ancient Greek tense, aspect and modality, ed. by Klaas Bentein, Mark Janse \& Jorie Soltic, 261-286. Leiden \& Boston: Brill. 